\title{
DATING-A Computer Code for Determining Allowable Temperatures for Dry Storage of Spent Fuel in Inert and Nitrogen Gases
}

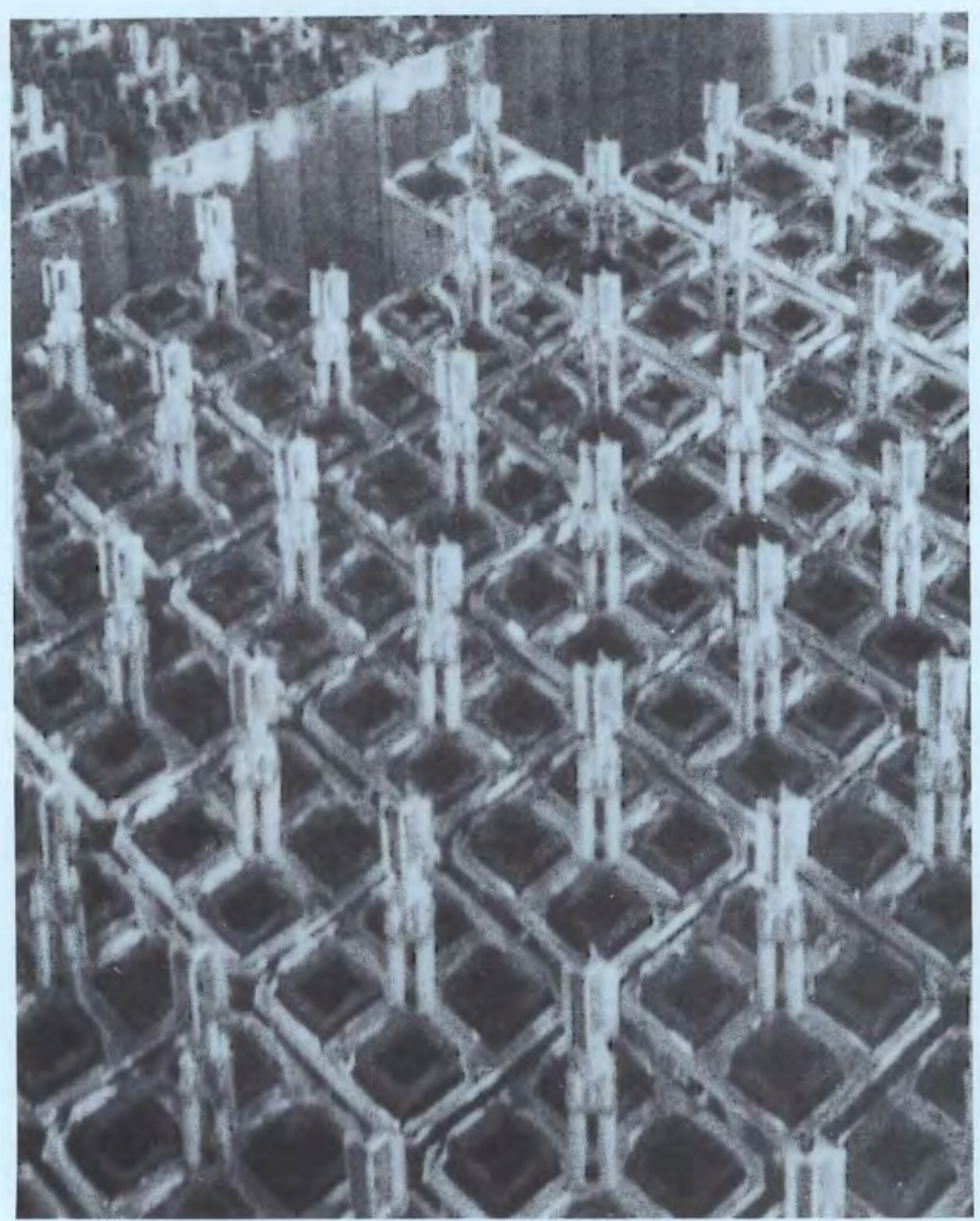

December 1988

Prepared for the U.S. Department of Energy under Contract DE-AC06-76RLO 1830

Pacific Northwest Laboratory Operated for the U.S. Department of Energy by Battelle Memorial Institute 


\title{
DISCLAIMER
}

This report was prepared as an account of work sponsored by an agency of the United States Government. Neither the United States Government nor any agency thereoi, nor Battelle Memorial Institute, nor any or their employees, makes any warranty, expressed or implied, or assumes any legal liability or responsibility for the accuracy, completeness, or usefulness of any information, apparatus, product, or process disclosed, or represents that its use would not infringe privately owned rights. Reference herein to any specific commercial product, process, or service by trade name, trademark, manufacturer, or otherwise does not necessarily constitute or imply its endorsement, recommendation, or favoring by the United States Government or any agency thereof, or Battelle Memorial Institute. The views and opinions of authors expressed herein do not necessarily state or reflect those of the United States Government or any agency thereof.

\author{
PACIFIC NORTHWEST LABORATORY \\ operated by \\ BATTELLE MEMORIAL INSTITUTE \\ for the \\ UNITED STATES DEPARTMENT OF ENERGY \\ under Contract DE-AC06-76RLO 1830
}

\author{
Printed in the United States of America \\ Available from \\ National Technical Information Service \\ United States Department of Commerce \\ 5285 Port Royal Road \\ Springfield, Virginia 22161 \\ NTIS Price Codes \\ Microfiche A01 \\ Printed Copy
}

$\begin{array}{cc}\begin{array}{c}\text { Pages } \\ 001-025\end{array} & \begin{array}{c}\text { Price } \\ \text { Codes }\end{array} \\ 026-050 & \text { A02 } \\ 051-075 & \text { A03 } \\ 076-100 & \text { A04 } \\ 101-125 & \text { A05 } \\ 126-150 & \text { A06 } \\ 151-175 & \text { A07 } \\ 176-200 & \text { A08 } \\ 201-225 & \text { A09 } \\ 226-250 & \text { A10 } \\ 251-275 & \text { A11 } \\ 276-300 & \text { A12 } \\ & \text { A13 }\end{array}$


PNL -6639

UC-85

DATING - A COMPUTER CODE FOR

DETERMINING ALLOWABLE TEMPERATURES

FOR DRY STORAGE OF SPENT FUEL

IN INERT AND NITROGEN GASES

E. P. Simonen

E. R. Gilbert, Project Manager

December 1988

Prepared for

the U.S. Department of Energy

under Contract DE-ACO6-76RLO 1830

Pacific Northwest Laboratory

Richland, WA 99352 


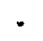

- 


\section{$\underline{\text { ABSTRACT }}$}

The DATING (Determining Allowable Iemperatures in Inert and Nitrogen Gases) code can be used to calculate allowable initial temperatures for dry storage of light-water-reactor spent fuel. The calculations are based on the life fraction rule using both measured data and mechanistic equations as reported by Chin et al. (1986). The code is written in FORTRAN and utilizes an efficient numerical integration method for rapid calculations on IBMcompatible personal computers. This report documents the technical basis for the DATING calculations, describes the computational method and code statements, and includes a user's guide with examples. The software for the DATING code is available through the National Energy Software Center operated by Argonne National Laboratory, Argonne, Illinois 60439. 


\section{CONTENTS}

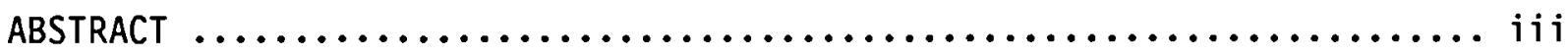

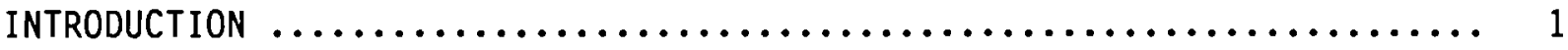

BACKGROUND $\ldots \ldots \ldots \ldots \ldots \ldots \ldots \ldots \ldots \ldots \ldots \ldots \ldots \ldots \ldots \ldots \ldots \ldots \ldots \ldots \ldots \ldots \ldots \ldots \ldots$

OVERVIEW OF LIFE FRACTION CONCEPT $\ldots \ldots \ldots \ldots \ldots \ldots \ldots \ldots \ldots \ldots \ldots$

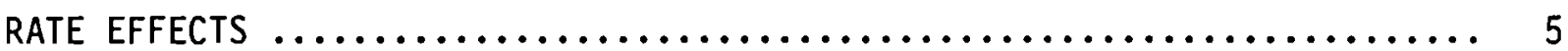

TEMPERATURE DECAY $\ldots \ldots \ldots \ldots \ldots \ldots \ldots \ldots \ldots \ldots \ldots \ldots \ldots \ldots \ldots \ldots \ldots \ldots \ldots \ldots \ldots \ldots \ldots \ldots$

Storage in Helium $\ldots \ldots \ldots \ldots \ldots \ldots \ldots \ldots \ldots \ldots \ldots \ldots \ldots \ldots$

Storage in Nitrogen $\ldots \ldots \ldots \ldots \ldots \ldots \ldots \ldots \ldots \ldots \ldots \ldots \ldots$

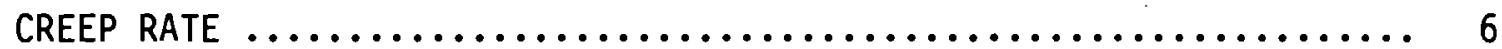

CREEP RUPTURE $\ldots \ldots \ldots \ldots \ldots \ldots \ldots \ldots \ldots \ldots \ldots \ldots \ldots \ldots \ldots \ldots \ldots \ldots \ldots \ldots \ldots$

ANNEALING OF RADIATION DAMAGE $\ldots \ldots \ldots \ldots \ldots \ldots \ldots \ldots \ldots \ldots \ldots \ldots \ldots$

COMPUTATIONAL METHOD $\ldots \ldots \ldots \ldots \ldots \ldots \ldots \ldots \ldots \ldots \ldots \ldots \ldots \ldots \ldots \ldots \ldots$

CUMULATIVE-DAMAGE FRACTION $\ldots \ldots \ldots \ldots \ldots \ldots \ldots \ldots \ldots \ldots \ldots \ldots \ldots \ldots \ldots \ldots$

DETERMINATION OF TEMPERATURE LIMIT $\ldots \ldots \ldots \ldots \ldots \ldots \ldots \ldots \ldots \ldots \ldots \ldots$

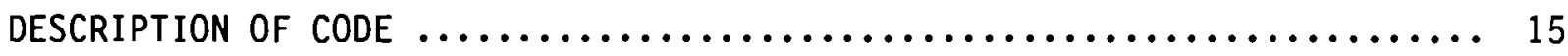

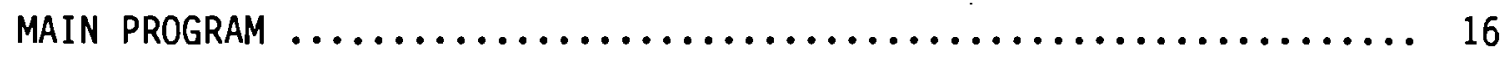

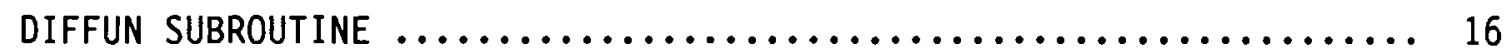

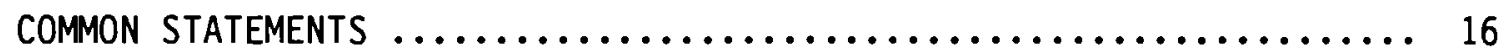

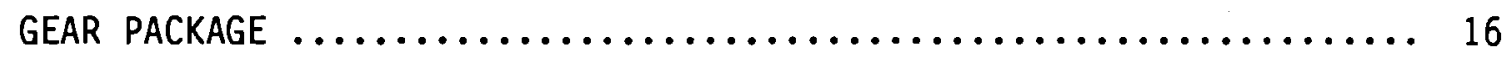

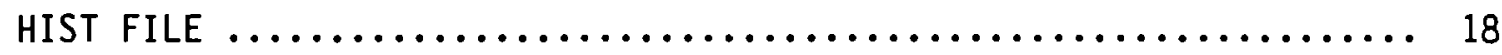

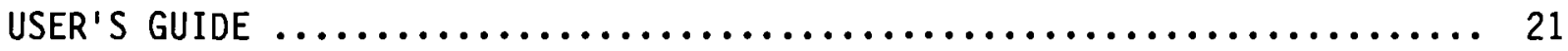

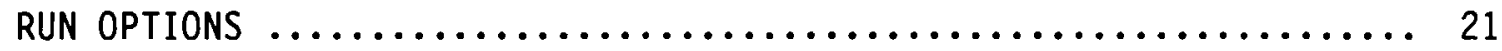

Temperature Limit Example ....................... 24

Verification Example $\ldots \ldots \ldots \ldots \ldots \ldots \ldots \ldots \ldots \ldots \ldots \ldots \ldots . \ldots \ldots$

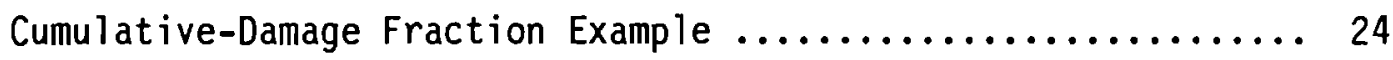




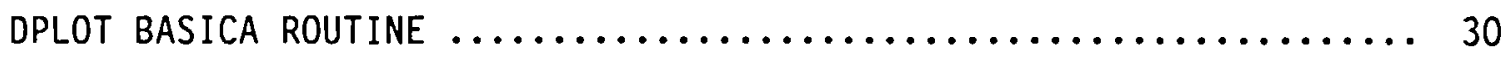

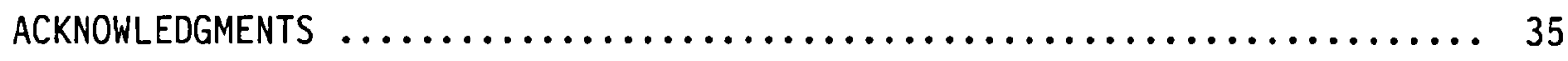

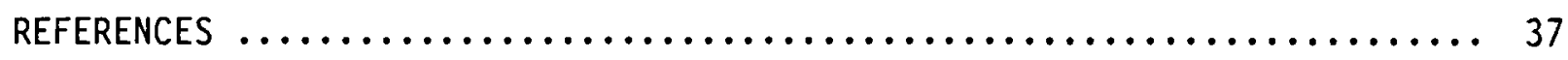

APPENDIX A - LISTING OF MAIN PROGRAM $\ldots \ldots \ldots \ldots \ldots \ldots \ldots \ldots \ldots \ldots \ldots \ldots . . \ldots \ldots$

APPENDIX B - LISTING OF DIFFUN SUBROUTINE $\ldots \ldots \ldots \ldots \ldots \ldots \ldots \ldots \ldots \ldots . . \ldots \ldots$

APPENDIX $C$ - LISTING OF COMMON.FOR $\ldots \ldots \ldots \ldots \ldots \ldots \ldots \ldots \ldots \ldots \ldots \ldots \ldots \ldots \ldots \ldots \ldots \ldots \ldots \ldots$

APPENDIX D - LISTING OF DPLOT.BAS $\ldots \ldots \ldots \ldots \ldots \ldots \ldots \ldots \ldots \ldots \ldots \ldots \ldots \ldots \ldots \ldots \ldots \ldots \ldots$ 


\section{FIGURES}

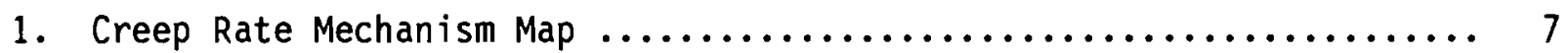

2. Creep Rupture Mechanism Map $\ldots \ldots \ldots \ldots \ldots \ldots \ldots \ldots \ldots \ldots \ldots \ldots . \ldots . \ldots . \ldots$

3. Cumulative Damage Fraction Versus Temperature and Stress ......... 13

4. Flow Chart for Temperature-Stress Limit and Cumulative Damage Fraction Calculations ................... 22

5. Flow Chart for Verification Calculations $\ldots \ldots \ldots \ldots \ldots \ldots \ldots \ldots$

6. Temperature Limit Comparing Results of DATING and Chin $\ldots \ldots \ldots \ldots$

7. Difference in Temperature Limit Between DATING and Chin ......... 26

8. Example Plot of Cumulative Damage Fraction Versus Time ......... 33

\section{$\underline{\text { TABLES }}$}

1. MAIN Program's Specific Lines and Their Functions ............. 17

2. DIFFUN Subroutine's Specific Lines and Their Functions .......... 18

3. Example Output of Temperature/Stress Limit ................. 27

4. Example Output of Verify Creep Rate, Rupture Time ............. 28

5. Example Output of Cumulative Fraction Versus Time $\ldots \ldots \ldots \ldots \ldots \ldots . \ldots 31$ 


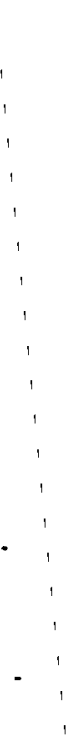




\section{INTRODUCTION}

\section{BACKGROUND}

Creep rupture has been identified as the principal failure mechanism for spent fuel cladding during dry storage in inert or nitrogen gas. The temperatures and stresses during dry storage must be maintained low enough to prevent significant creep during storage. A maximum temperature limit, based on accumulated strain to fracture, has been recommended (Cunningham 1987) for storage of spent fuel; however, the temperature limit required to ensure that the cladding remain intact is dependent upon characteristics of the fuel and design of the dry storage system.

Chin et al. (1986) developed a technical basis for calculating limits based on specific fuel and dry storage system designs. The technical approach for calculating the temperature limit used a creep-rate- and creeprupture-map concept in which changes in mechanism with decreasing temperature could be accounted for when calculating creep strain and rupture lifetimes. The creep rupture model has been presented and verified previously (Chin et al. 1986; Levy et al. 1987); however, this numerical computer model required hours of computation time and, hence, was not practical for determining temperature limits for the wide variety of conditions of interest for evaluating dry storage options. Furthermore, the code was written in the Hewlett-Packard language and could be used only on Hewlett-Packard computers.

The DATING Code was developed to provide a method of incorporating the Chin model on IBM-compatible personal computers. DATING is written in the FORTRAN computer language and can be compiled and executed on any computer which is compatible with the FORTRAN language. The code is being made available to the public for evaluation of dry storage options and to ensure compliance with NUREG 10CFR Part 72, Licensing Reguirements for the Storage of Spent Fuel in an Independent Spent Fuel Storage Installation (ISFSI).

\section{OVERVIEW OF LIFE FRACTION CONCEPT}

The DATING computer code is based on calculating limiting conditions for dry storage of spent fuel based on creep-strain limits for fuel cladding and does not include other failure mechanisms such as those related to hydrogen. 
Metallurgical tests for creep-strain limits are typically performed at constant temperature, whereas cladding-creep strain occurs during cooling (governed by radioactive decay) of spent fuel in storage. The constant temperature test data cannot be used directly to accurately predict creep strain and temperature limits. Variable conditions during dry storage, therefore, are accounted for by using a cumulative life-fraction model.

The cumulative life-fraction model assumes that the creep-rupture limit during temperature and stress transients can be estimated by summing damage which occurs in increments of time. The fraction of life consumed at the temperature and stress during each time increment is calculated and summed. The creep-rupture limit is assumed to be achieved when the sum of the incremental life fractions equals unity. The DATING computer code uses the life-fraction model to evaluate cladding integrity during dry storage of spent fuel.

Initial conditions (temperature and stress) are assumed and the fraction of cumulative damage occurring in each time step is integrated to a given time of storage. If the fraction is less than unity for the assumed initial temperature and stress, that condition is considered allowable for the drystorage time considered. The maximum temperature for a given stress that results in a damage fraction equal-to or less-than unity is defined as the maximum allowable temperature for dry storage. The calculated rupture lifetime in DATING is adjusted to account for the reduced Zircaloy cladding ductility associated with the radiation damage. Radiation is assumed to reduce the rupture lifetime by a factor of ten. Annealing of radiation damage is calculated and the penalty on rupture time is reduced in proportion to the calculated fraction of damage annealed during storage.

The maps of creep-strain and creep-rupture time, which are included in the DATING model, allow the rupture lifetime to be calculated using the appropriate limiting creep mechanism (fastest creep) and limiting rupture mechanism (usually, the least time). The mechanistic equations have been adjusted to fit published creep-rate and rupture-time experimental data. Similarly, the annealing kinetics for radiation damage are based on published annealing kinetics experimentally determined by Steinberg, Weidinger, and Schaa (1984). 
Analytical integration of the life fraction cannot be obtained because of the complicated forms of equations for temperature decay, creep rate, rupture life time, and radiation-damage annealing. Therefore, numerical methods are required to integrate the life fraction over time. The numerical computer code developed by Chin et al. (1986) uses a constant time step. The DATING numerical method uses a variable time step selected by the computer package called GEAR (Hindmarsh 1974). The computational efficiency for the variable time-step method greatly exceeds that for a constant timestep method while providing the same accuracy.

The calculation of life fraction during dry storage requires consideration of time-dependent temperature decay, and the time and temperature dependent effects of creep and annealing of radiation damage. These rate effects are described in the next section. 
-

.

-

. 


\section{RATE EFFECTS}

\section{IEMPERATURE DECAY}

The decay of radioisotopes during dry storage results in a decreasing temperature of the fuel cladding and, consequently, decreasing internal pressure and cladding-hoop stress level with increasing storage time. Thus, the rate of temperature decay is required for calculating creep rate and rupture time as a function of fuel storage time; the temperature decay is also dependent on the heat-transfer characteristics of the dry storage system. The temperature-time history of the fuel can be input through equations, such as those used for storage in helium or nitrogen, or in userspecified tabular form provided by the file, HIST.

\section{Storage in Helium}

For spent fuel stored in helium gas, DATING assumes a temperature decay function, derived by Levy et al. (1987), which has a two-parameter fit, i.e., the temperature is assumed to be the maximum of two temperatures $\left(T_{1}\right.$ or $\left.T_{2}\right)$, where

$$
\begin{aligned}
& T_{1}=T_{a}\left(t / t_{u}\right)-0.34 \\
& T_{2}=T_{b}\left(t / t_{u}\right)-0.084 \\
& T_{b}=T_{a} \frac{70.084}{70.34}
\end{aligned}
$$

The constant $T_{a}$ is determined by the fuel temperature in the storage system. Time, $t$, is expressed in years after discharge from reactor, $t_{u}$ is 1 year, and temperature is expressed in $K$. At times less than 7 years, $T_{1}$ is used. Whereas, at times longer than 7 years, $T_{2}$ applies. A fuel burnup of $30 \mathrm{MWd} / \mathrm{kgM}$ is assumed.

\section{Storage in Nitrogen}

For storage in nitrogen gas, the time dependence of temperature is assumed to have the following form for a fuel burnup of $30 \mathrm{MWd} / \mathrm{kgM}$ :

$$
\ln (T-273)=a_{0}+a_{1} \cdot \ln (\text { time })
$$


The coefficients ao and $a_{1}$ depend on burnup, B in MWd/kgU, and time in years. For times from 2 to 5 years,

$$
\begin{aligned}
& a_{0}(B)=\exp \left[1.455+0.204 \cdot \ln (B)-0.2391 \cdot 10-1 \cdot \ln (B)^{2}\right] \\
& a_{1}(B)=-1.0339+0.0094 \cdot B
\end{aligned}
$$

For times greater than 5 years,

$$
\begin{aligned}
& \mathrm{a}_{0}(B)=\exp [1.167+0.169 \cdot \ln (B)] \\
& \mathrm{a}_{1}(B)=-0.51391 \cdot 10-1-0.98780 \cdot 10-2 \cdot B+0.92362 \cdot 10-4 \cdot B^{2}
\end{aligned}
$$

As for the helium gas case, the larger of the two temperatures is used by DATING.

\section{CREEP RATE}

The dominant creep rate mechanism depends on temperature and stress as seen in Figure 1. The creep rate is calculated for each of the five mechanisms, and the maximum rate is selected as the appropriate dominant rate for calculated cumulative-damage fraction. The temperature at each time is compared to the temperature limit for athermal creep. If the cladding temperature is below the athermal limit, then the creep rate is calculated based on the temperature at the athermal limit, not on the actual cladding temperature which is below the limit.

Creep mechanisms are known to depend on stress and temperature levels. At low stress levels, diffusional creep processes dominate. Whereas, at high-stress and high-temperature levels, dislocation climb is the rate controlling creep process. At high stresses, dislocation climb controls the creep rate. At low stresses, grain boundary sliding is the controlling creep mechanism. At stresses above $100 \mathrm{MPa}$, the temperature decay associated with dry storage results in conditions at which the creep is controlled initially by dislocation climb and is controlled at later times by grain boundary sliding. 


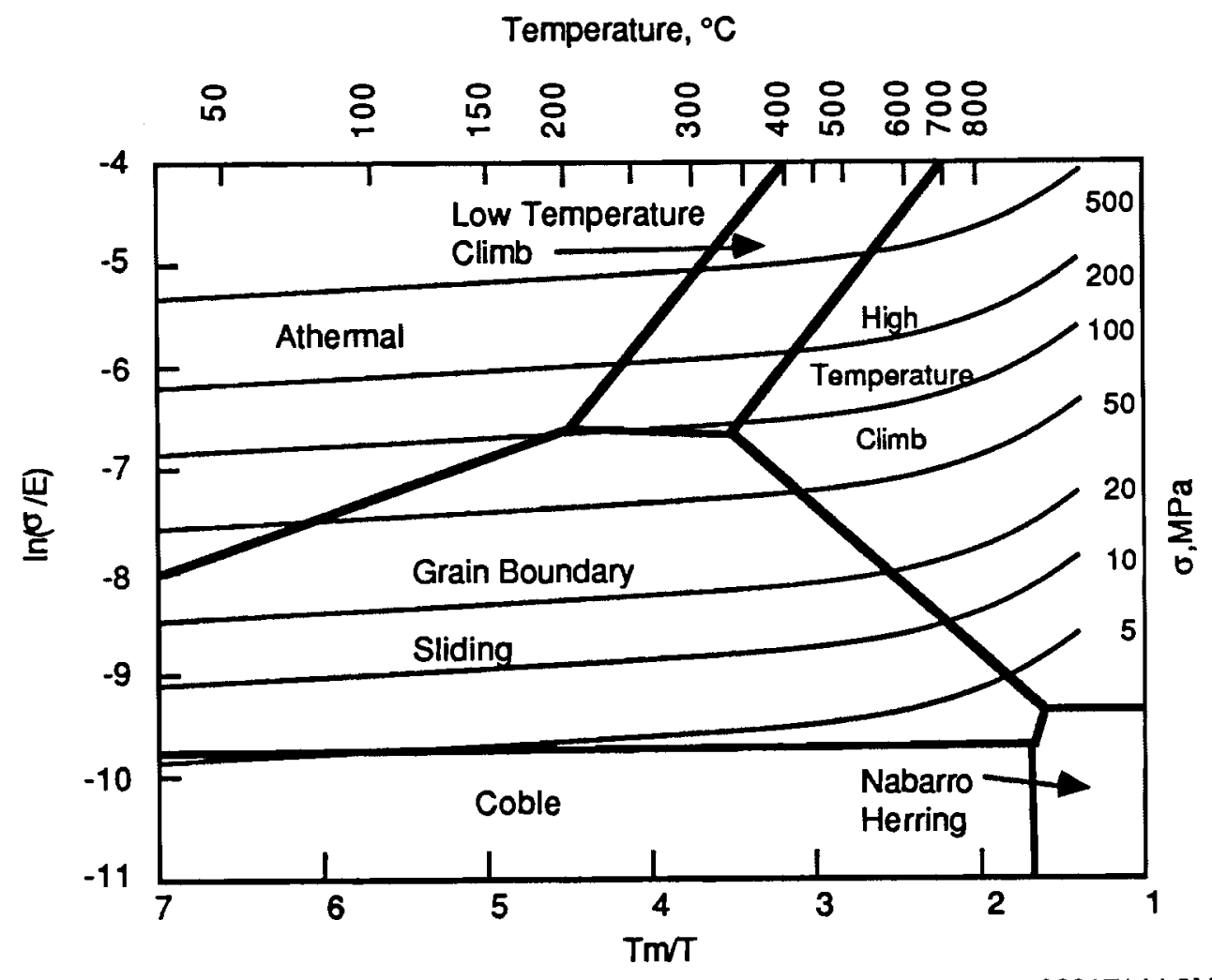

FIGURE 1. Creep-Rate Mechanism Map

The equations for the relevant creep mechanisms are given below for high-temperature climb, low-temperature climb, grain boundary sliding, Nabarro-Herring creep, and Coble creep. The equations are expressed in their reduced form as used in DATING. The corresponding mechanism equations and parameter values are given by Chin et al. (1986) which excludes calculating a creep rate for grain boundary lattice diffusion control. Therefore, DATING outputs a value of zero for that mechanism.

High-Temperature $\mathrm{Climb}$ :

$$
\ln \dot{\epsilon} H T=5 \cdot \ln (\sigma / E)+55.75-14.15\left(\frac{T M}{T}\right)+\ln \left(\frac{T M}{T}\right)+\ln \left(\frac{E}{10^{4}}\right)
$$


Low-Temperature Climb:

$$
\ln \dot{\epsilon} L T=7 \cdot \ln (\sigma / E)+55.18-10.19\left(\frac{T M}{T}\right)+\ln \left(\frac{T M}{T}\right)+\ln \left(\frac{E}{104}\right)
$$

Grain Boundary Sliding:

$$
\ln \dot{E} G B S=2 \cdot \ln (\sigma / E)+20.74-9.9200\left(\frac{T M}{T}\right)+\ln \left(\frac{T M}{T}\right)+\ln \left(\frac{E}{10^{4}}\right)
$$

Nabarro Herring:

$$
\ln \dot{E} N H=\ln (\sigma / E)+18.25-14.15\left(\frac{T_{M}}{T}\right)+\ln \left(\frac{T_{M}}{T}\right)+\ln \left(\frac{E}{104}\right)
$$

Coble:

$$
\ln \dot{\varepsilon} C O=\ln (\sigma / E)+11.03-9.9200\left(\frac{T_{M}}{T}\right)+\ln \left(\frac{T_{M}}{T}\right)+\ln \left(\frac{E}{104}\right)
$$

where $\dot{\epsilon}=$ creep rate, $\mathrm{s}^{-1}$

$\sigma=$ stress, $\mathrm{MPa}$

$E=$ elastic modulus, MPa

$T_{M}=$ melting temperature, $K$

$T=c l a d d i n g$ temperature, $K$

\section{CREEP RUPTURE}

The creep-rupture mechanisms also depend on temperature and stress as shown in Figure 2. Cavitation-rupture mechanisms control lifetimes for drystorage temperatures and stresses. At low stresses (approximately less than $100 \mathrm{MPa})$, cavitation-diffusion-controlled rupture dominates. At high stresses, cavitation-power-1aw rupture dominates. A transition from diffusion control to power-law control of the rupture mechanism occurs during dry storage for initial stresses above $100 \mathrm{MPa}$. Additional creep-rupture 


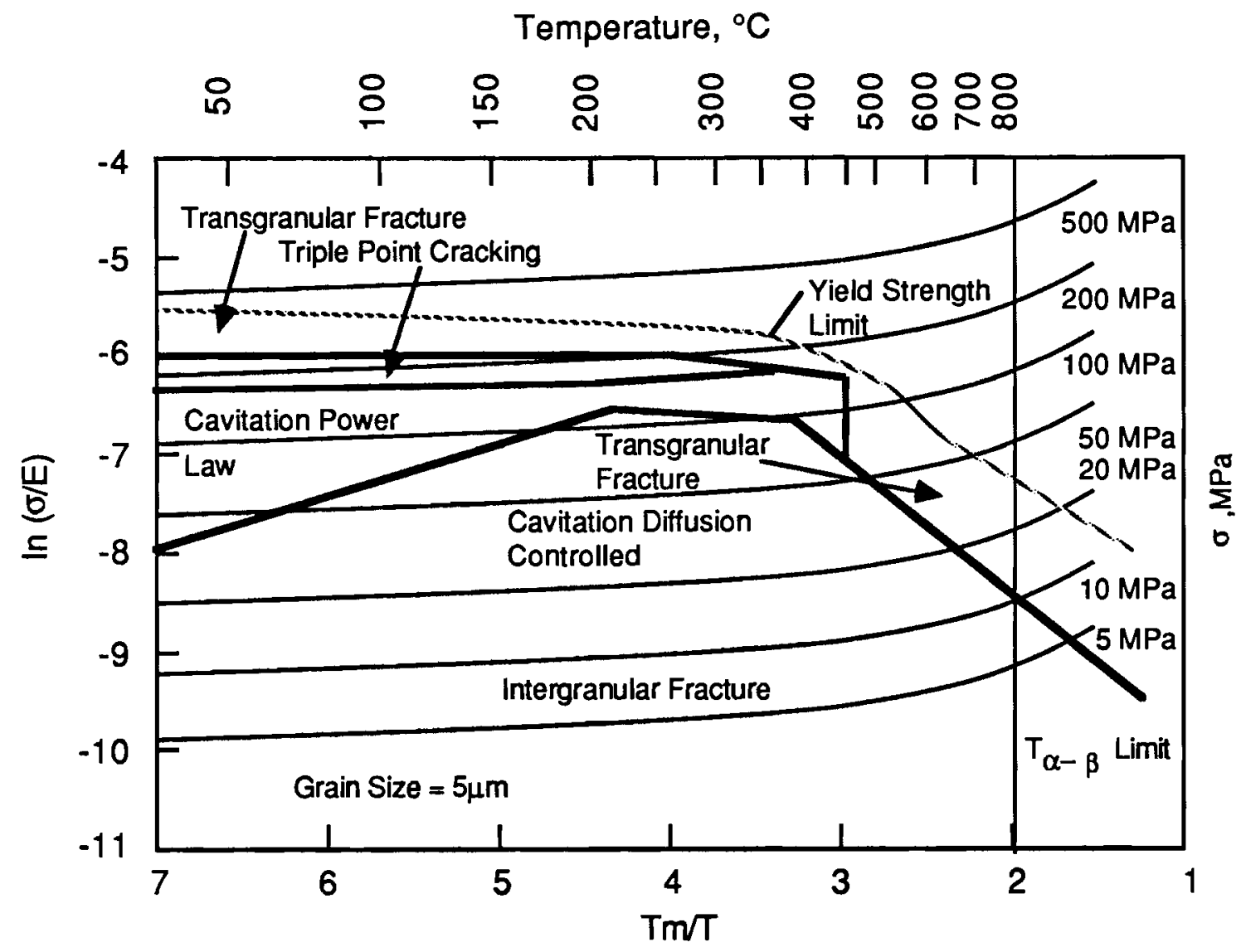

$38807144.1 M$

\section{FIGURE 2. Creep-Rupture Mechanism Map}

mechanisms for Zircaloy cladding include transgranular cracking near the yield stress and triple-point-cracking, also at high stresses. These latter two mechanisms are included in DATING for completeness but are not expected to occur for typical dry storage temperatures and stress conditions.

The rupture mechanism equations used in DATING are given below for transgranular cracking, triple-point-cracking, cavitation-power-law, and cavitation-diffusion-controlled rupture. The reduced equations are given and are based on mechanism equations and parameters described by Chin et al. (1986). The rupture time, $t_{f}$, is in seconds.

Transgranular:

$$
\ln t_{f} T G=-1.797-\ln \dot{\epsilon}
$$


Triple Point Cracking:

$$
\ln \mathrm{t}_{f}{ }^{T P}=-5.662-\ln \dot{\epsilon}-\ln (\sigma / E)-\ln \left(E / 10^{4}\right)
$$

Cavitation Diffusion:

$$
\ln \mathrm{t}_{f} \mathrm{CD}=4.15-\ln \dot{\epsilon} \mathrm{GBS}+\ln (\sigma / \mathrm{E})
$$

where $\dot{\epsilon} G B S$ is the grain boundary sliding creep rate in $s^{-1}$.

Cavitation Power Law:

$$
\ln \mathrm{t}_{\mathrm{f}} \mathrm{CP}=-1.587-\ln \dot{\epsilon}
$$

\section{ANNEALING OF RADIATION DAMAGE}

Radiation damage is assumed to reduce the ductility of the cladding and, hence, its rupture lifetime compared to the unirradiated cladding. At elevated temperature, the radiation damage can anneal out and restore the ductility to that of unirradiated cladding. The assumption is made that radiation damage reduces the ductility and, hence, the creep-rupture time to $10 \%$ of its unirradiated ductility. With increasing time-at-temperature, more radiation damage is assumed to anneal out until the full unirradiated ductility is restored. The annealing rate is assumed to follow the temperature-dependent equation shown below for the dimensionless recovery factor, $r$ :

$$
r=1-0.9\left[\frac{1}{1+\sum_{i=1}^{n} \delta t \cdot R \cdot \exp \left(-4 \cdot 104 / T_{i}\right)}\right]
$$

The rate constant, $R$, is $2.332 \times 1017 \mathrm{~s}^{-1}$ and $T$ is the absolute temperature in $k$. The time increment for summation is $\delta t$ in $s$. 
COMPUTATIONAL METHOD

The cumulative-damage fraction is integrated from the specified initial fuel age to the specified end-of-life age for a given temperature and stress history using the creep rate and rupture-time equations. The time step for the integration is controlled by the GEAR subroutine package (Hindmarsh 1974), and is adjusted to provide a solution with a minimum number of time steps while maintaining control of the numerical error. The allowable temperature/stress limit for storage corresponds to a damage fraction of unity for a specified initial temperature and stress.

\section{CUMULATIVE-DAMAGE FRACTION}

For a given initial stress and temperature, DATING calculates the time dependence of cumulative-damage fraction. The temperature and stress at each time step are calculated analytically from the equations for the decay of temperature and stress. The creep rate and annealing rate are calculated to obtain the estimated rate of accumulating damage fraction. The initial time

step is $100 \mathrm{~s}$. If that is too large for control of error, then GEAR automatically reduces the initial time step until it is small enough to pass the error-control test. The time step is adjusted by GEAR to be as large as possible while maintaining appropriate control of the error.

The creep rate and rupture mechanisms depend on temperature and stress as seen in Figures 1 and 2 . The creep rate is calculated for each of the five mechanisms and the maximum rate is selected as the appropriate dominant rate for calculated cumulative-damage fraction. The temperature at each time is compared to the temperature limit for athermal creep. If the cladding temperature is below the athermal limit, then the creep rate is calculated based on the temperature at the athermal limit, not the actual cladding temperature which is below the limit.

Similarly, the rupture time depends on temperature and stress. The rupture time used in the cumulative-fraction calculation is generally obtained by determining the mechanism exhibiting the minimum rupture time for the temperature and stress of interest. Exceptions to this rule exist for high temperature and/or high stress. Specifically, at temperatures greater 
than $435^{\circ} \mathrm{C}$, the rupture time is assumed to be the minimum of the transgranular rupture time and the cavitation-diffusion-controlled rupture time. Also, triple-point cracking was not allowed to be the controlling mechanism near the yield stress. Therefore, the mechanism boundary between transgranular fracture and triple-point-cracking was adjusted in the temperature range from 258 to $435^{\circ} \mathrm{C}$ as indicated in Figure 2. At stresses above the indicated boundary, the transgranular-fracture rupture times are assumed to dominate for the calculation of cumulative-damage fraction.

The radiation-damage annealing rate is assumed to be independent of stress and dependent on temperature as indicated in Equation 8. The accumulated annealing fraction is calculated, and used to estimate the reduction in rupture lifetime. The rupture life for cold-worked, irradiated Zircaloy is assumed to be $10 \%$ of that of the unirradiated material.

\section{DETERMINATION OF TEMPERATURE LIMIT}

The allowable temperature limit is determined by estimating the maximum temperature for which the cumulative fraction does not exceed unity at the specified end-of-life, nominally 40 years. For a given stress, there is a temperature which corresponds to a cumulative fraction of unity as seen in Figure 3. DATING uses a numerical search procedure to determine this temperature.

To establish an initial estimate of allowable temperature, the cumulative fraction is initially calculated at $340^{\circ} \mathrm{C}$ and $360^{\circ} \mathrm{C}$. Based on the cumulative fraction at those two temperatures, a linear relationship is established between reciprocal temperature and cumulative-damage fraction. A new estimate of temperature corresponding to a cumulative fraction of unity is calculated. The correct cumulative fraction is then calculated for that revised temperature. If the correct cumulative fraction is greater than unity, an updated linear relationship is established based on the revised temperature and the revised temperature less $20^{\circ} \mathrm{C}$. If the correct cumulative fraction is less than unity, then the relationship is based on the revised temperature and the revised temperature plus $20^{\circ} \mathrm{C}$.

With each iteration an improved estimate of the temperature corresponding to a cumulative fraction of unity is obtained. When the newer 


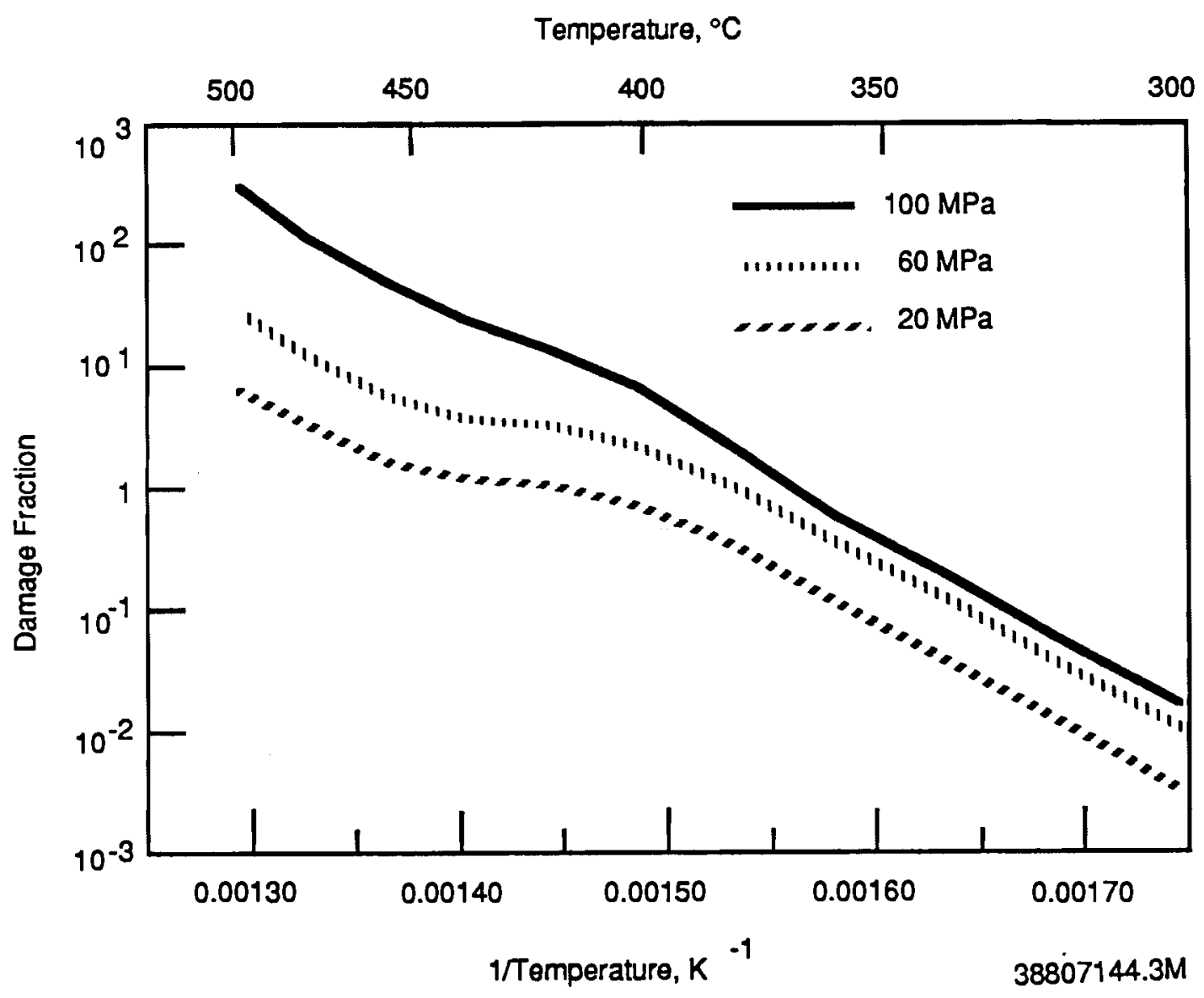

FIGURE 3. Cumulative Damage-Fraction Versus Temperature and Stress

estimate of temperature is less than $1^{\circ} \mathrm{C}$ different from the previous estimate, the search is concluded, and the temperature is output as the temperature limit for the assumed stress. At low temperatures, where cavitationdiffusion control dominates, the temperature limit is determined with only three calculations of cumulative fraction. At higher temperatures, as many as ten calculations of cumulative-damage fraction may be necessary. 


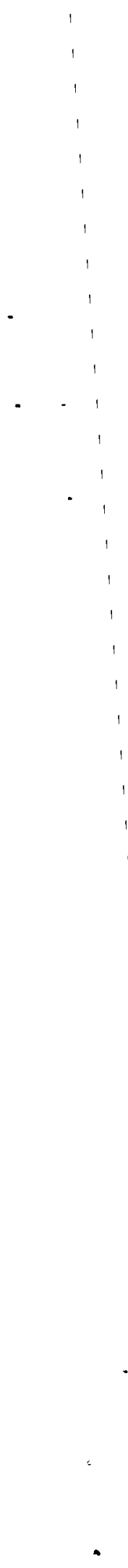




\section{DESCRIPTION OF CODE}

The DATING code computes creep behavior of Zircaloy cladding for timedependent temperature and stress histories. Creep strain, radiation-damage annealing, and cumulative life-fraction are integrated for user-specified temperature and stress histories. The temperature must be below the alpha/beta transition temperature, $800^{\circ} \mathrm{C}$, for Zircaloy. The stress must be below the yield stress. Note that Figure 1 indicates that the NabarroHerring creep mechanism dominates only for temperatures above $800^{\circ} \mathrm{C}$ and therefore is not allowed in DATING calculations.

Although the principal purpose of the code is to provide estimates of allowable temperature limits, the code also provides estimates for creep strain, annealing fraction and life fraction as a function of storage time. Equations for the temperature of spent fuel in inert and nitrogen gas storage are included explicitly in the code; however, an option is included for a user-specified cooling history in tabular form. Also, an option is contained in the DATING code for creating tables of the temperature and stress dependencies of creep-strain rate and creep-rupture time for Zircaloy at constant temperature and constant stress or constant ratio of stress/modulus.

The DATING code consists of three components: a) the MAIN program, b) the DIFFUN subroutine, and c) the GEAR package. In addition, the file COMMON.FOR contains common statements used in MAIN and DIFFUN. The MAIN program establishes input parameters, initial conditions, GEAR options, and output of data. The DIFFUN subroutine contains the rate equations which are simultaneously integrated using the GEAR package. The GEAR package is a set of subroutines for the numerical solution of the rate equations specified in DIFFUN. The rate equations include the creep rate, the rate of radiation damage annealing, and the rate of accumulating creep damage. Lastly, the user must supply a data input file, HIST, for the case of the user-specified temperature history or temperature and stress history.

The results of the time-dependent cumulative damage-fraction calculations can be plotted using the BASICA program DPLOT.BAS. This program is written in BASICA language, and plots the time dependence of the calculated cumulative damage fraction, creep strain, radiation damage recovery, and the temperature decay. 


\section{MAIN PROGRAM}

The MAIN program contains the input options, calls subroutines DIFFUN and DRIVE (in GEAR), and outputs results of calculations. The input data is entered from the keyboard and the output data is written to the file DATING.OUT on the default drive. The user-specified temperature or temperature and stress history is read from the MAIN program. Specific lines and their functions are described in Table 1. Error messages result if the assumed stress is above the yield stress or if the temperature is above the $\alpha$ to $\beta$ transition temperature.

\section{DIFFUN SUBROUTINE}

The DIFFUN subroutine contains the rate equations used for the integration of creep strain, radiation-damage fraction annealed and accumulated creep-damage fraction. The parameters in the DIFFUN subroutine call include the number of rate equations NEQ, the time TT, the array $Y$ and the array YDOT. The arrays $Y$ and YDOT are the integrated values and the rates of change of the values being integrated. The DIFFUN subroutine is called from GEAR to perform the integration. Also, the subroutine is called from the MAIN program when the verification option is selected. Specific lines and their functions are described in Table 2.

\section{COMMON STATEMENTS}

COMMON statements used in MAIN and DIFFUN are included in the file named COMMON.FOR. Variables shared in common between the two program units are contained in this file.

\section{GEAR PACKAGE}

Details of the GEAR method options are discussed by Hindmarsh (1974). The GEAR package can be obtained from the National Energy Software Center at Argonne National Laboratory.

The DRIVE statement in the MAIN program calls on the GEAR package. The MAIN program also provides input options to run GEAR. These options include the initial time step, HO, the error-control parameter, EPS, and the method 
TABLE 1. MAIN Program's Specific Lines and Their Functions

Line Numbers

1 to 6

7 to 11

12 to 19

20 to 26

27 to 34

35 to 37

38 to 63

64 to 90

91 to 219

220 to 371

372 to 420

421 to 439

440 to 571

572 to 756

757 to 777

778 to 793

794 to 798
Function

Define program and compile options.

Define precision, dimension variables, and define COMMON statements.

Open output files.

Define array for yield stress calculation.

Initialize flags for output.

Define alpha-beta phase transition temperature.

Input options for DATING output.

Input options for verifying creep rate and rupture time calculations using DATING (IRUN $=2$ ).

Calculate creep rate/mechanism and rupture time/mechanism for a selected range of temperatures at constant stress or stress/modulus ratio (IOUT $=1$ or 2 ). DIFFUN called at line 152 .

Calculate creep rate/mechanism and rupture time/mechanism for a selected range of stresses or ratios of stress/modulus at constant temperatures. DIFFUN called at line 263 (IOUT $=3$ ) of at line $332($ IOUT $=4)$.

Output creep and rupture mechanism.

Initialize GEAR options (IRUN $=1$ or 3 ).

Select temperature/stress history and options; read HIST.

Integrate CF or determine allowable temperature limit. DRIVE called at line 652; DRIVE calls DIFFUN and GEAR.

Output GEAR run statistics, fuel age, and warning of athermal creep calculations.

Output HIST Table if used.

Stop and end run. 
TABLE 2. DIFFUN Subroutine's Specific Lines and Their Functions

Line Numbers

1 to 4

5 to 7

8 to 64

65 to 69

70 to 72

73 to 132

133 to 157

158 to 177

178 to 186
Function

Compile options and definition of subroutine.

Specify precision, dimension variables, and define COMMON statements.

Calculate temperature and stress.

Set NFLAGS if stress exceeds yield stress.

Calculate EM, elastic modulus.

Calculate reduced creep rate.

Calculate rupture time.

Define MFLAG for creep and rupture mechanisms.

Calculate rates of creep, radiation damage annealing, and cumulative creep damage.

187 to $188 \quad$ Return and end subroutine.

flag, MF. The initial time step is set at $100 \mathrm{~s}$ in MAIN. If a smaller time step is required, then GEAR will reduce the time step by an order of magnitude repeatedly until the time step satisfies the error-control criteria.

The EPS parameter is set at 0.0001 in the MAIN program, and has been found to be appropriate for the present applications. Larger values for EPS could result in unstable solutions; whereas, smaller values results in more integration steps without significant improvement in accuracy.

The method flag is set at 22 which causes the solution to be obtained using the backward-differentiation-formula method and the cord method with the Jacobian generated internally for the corrector iteration method.

\section{HIST FILE}

The user-specified temperature or temperature and stress history is contained in the file HIST. The first line in the file states the number (integer) of values of time that are in the list. A maximum of 50 values are allowed in the file. Each subsequent line contains the time, temperature and 
stress written with a decimal point. Numbers must be included in the stress column even when only the temperature history is used for the history option, "TABLE FORM." 
-

- 


\section{USER'S GUIDE}

The DATING code is run from keyboard input, and the output is written to a file on disk as well as to the screen. The purpose of this chapter is to describe the input options and to give example runs with output. The disc containing the DATING program may be placed in any drive, but the output will be written to the default drive. If the user wishes to write the output data on the same disc that contains DATING, then the user should place the DATING program disc in the default drive. To write the output on another drive, place the data disc in the desired default drive, and execute DATING with the specification of which drive DATING is on.

\section{RUN OPTIONS}

The input options are in two categories: 1) selection of output parameters and 2) selection of assumed values for temperature, stress or temperature-stress history. The first user option is to select whether 1) the allowable temperature limit for dry storage is desired, or 2) the creep rate and rupture magnitudes are to be verified, or 3 ) the cumulative fraction as a function of time is desired. These options appear on the screen as follows:

1. TEMPERATURE STRESS LIMIT

2. VERIFY CREEP RATE, RUPTURE TIME

3. CUMULATIVE DAMAGE FRACTION VS TIME

Each of these options lead to subsequent options for desired temperatures, stresses, or temperature/stress transients. Note that the above options must be entered as integers. A flow chart of DATING for options one and three is shown in Figure 4 and for option 2 the flow chart is shown in Figure 5.

The output examples in this section are for use in verifying that the program is producing the correct results on the user's computer. One example for each type of output option is given, namely, for the temperature limit, for the verification calculations, and for the cumulative-damage calculations. 


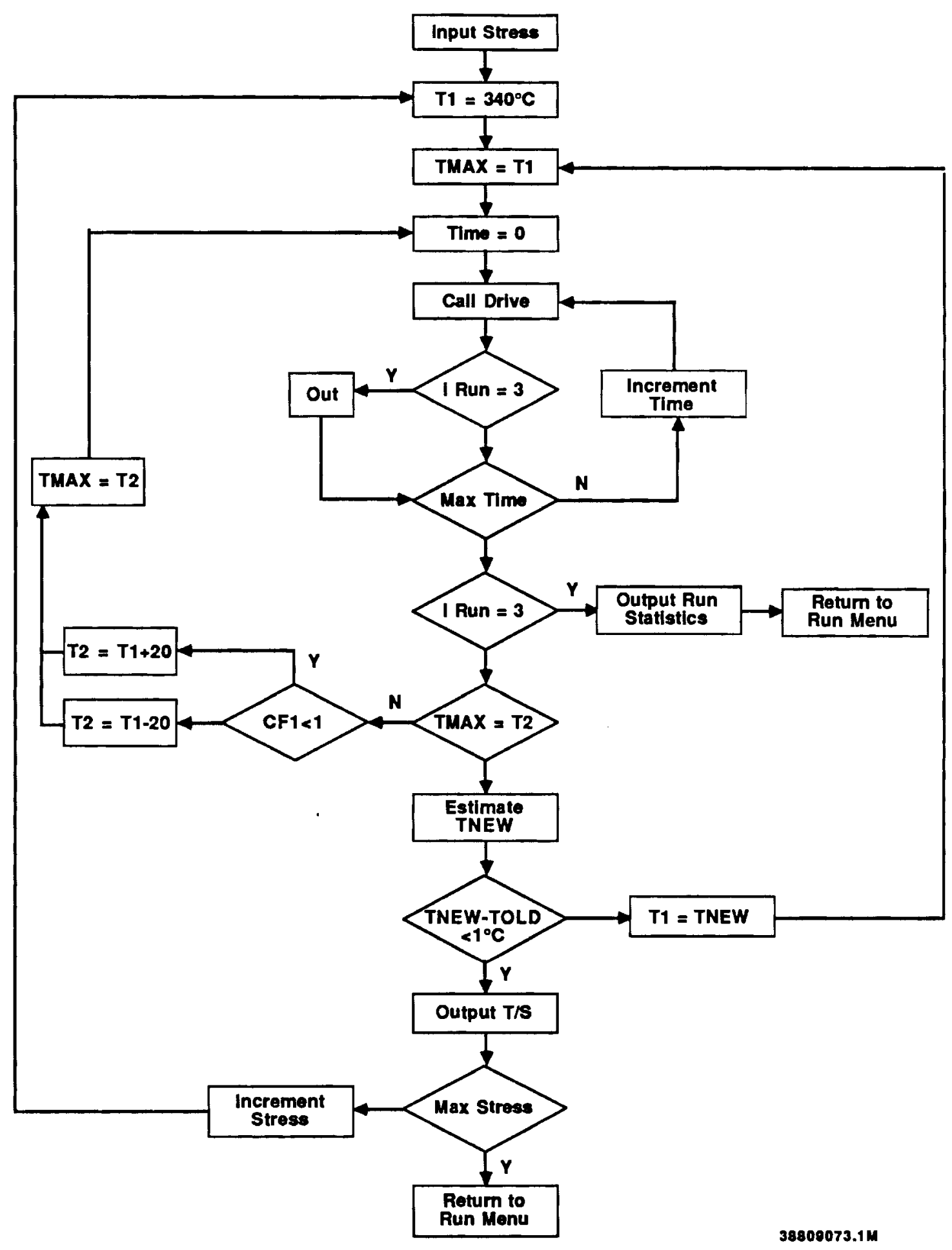

FIGURE 4. Flow Chart for Temperature-Stress Limit and Cumulative Damage Fraction Calculations 


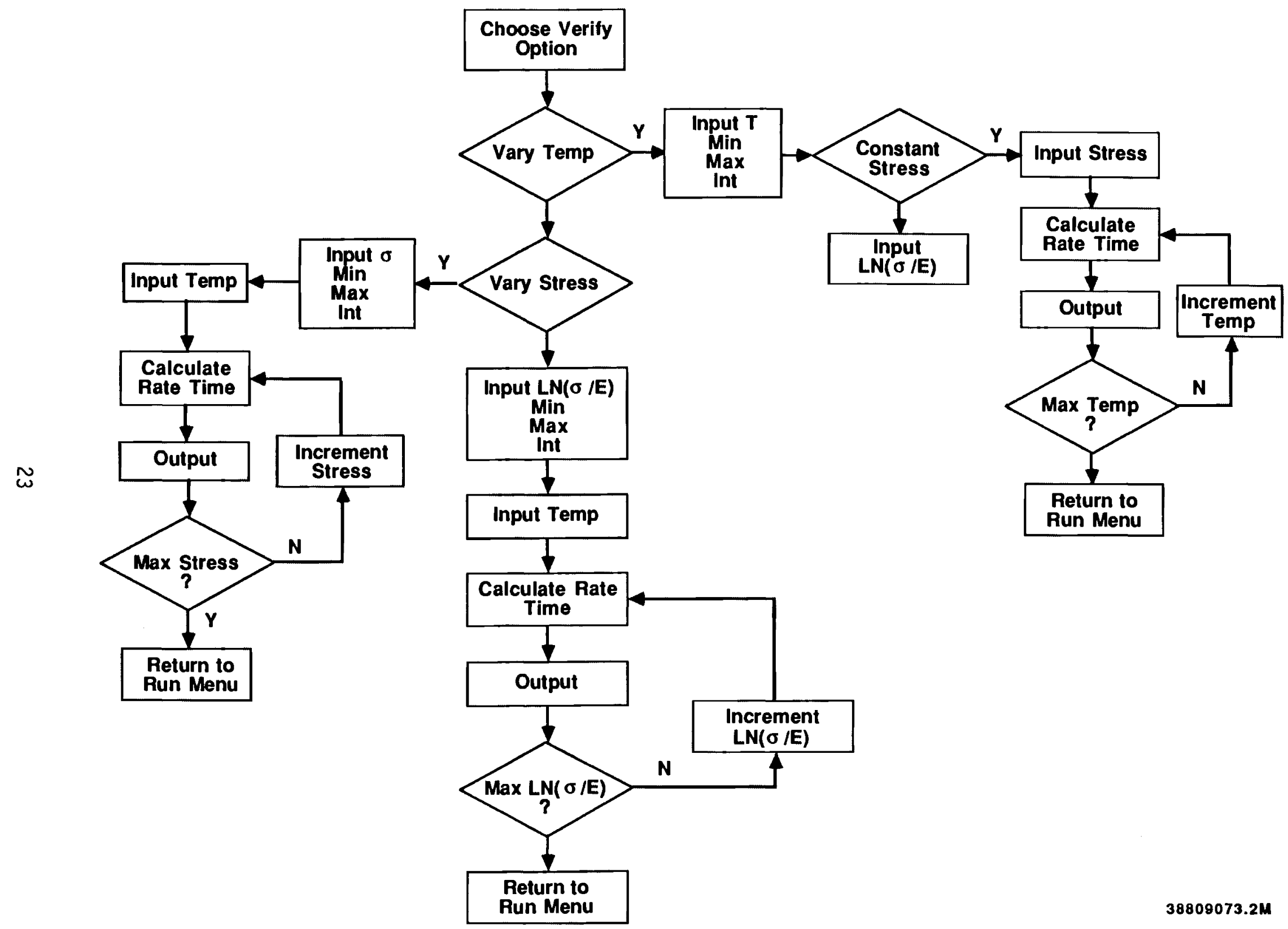

FIGURE 5. Flow Chart for Verification Calculations 


\section{Temperature Limit Example}

For calculations of the temperature-stress limit, the minimum stress, maximum stress, and stress interval are input as they are prompted on the screen. The stress is in units of MPa. The fuel age in years also has to be entered. Note that each input parameter is entered as an integer. Typically, the run time to determine the allowable temperature for one stress is about $1 \mathrm{~min}$. An example of the input and output format is shown in Table 3; the fuel age is 5 years, the storage is in helium, and the limit is output from 20 to $120 \mathrm{MPa}$ at $20 \mathrm{MPa}$ intervals. The results are plotted in Figure 6 and show excellent agreement with results reported by Chin et al. (1986) shown in Figure 7.

\section{Verification Example}

The verification calculations can be made over selected ranges of temperatures or stresses. The purpose of the verification option is to demonstrate that the creep mechanisms are predicted in the same manner reported by Chin. Also, this option can be used to generate tables of expected creep rates and rupture times for uses other than for dry storage. A maximum of 100 values of creep rate and rupture time can be calculated for the table. Options exist to generate tables based on variable temperature or variable stress. Furthermore, the stress range can be displayed as the LOG of stress normalized by the elastic modulus. The verification example in Table 4 is for a constant temperature, and the stress varies from $20 \mathrm{MPa}$ to $200 \mathrm{MPa}$ in intervals of $20 \mathrm{MPa}$.

\section{Cumulative-Damage Fraction Example}

The cumulative-damage fraction option requires entering the number of time steps which should be outputted, the time increment in years between outputted values, the initial temperature in ${ }^{\circ} \mathrm{C}$, the initial stress in $\mathrm{MPa}$, and the fuel age in years. Each value is entered as an integer except for the time increment which is a floating point variable. The run time for a typical damage-fraction integration to forty years takes as little as $10 \mathrm{~s}$. 


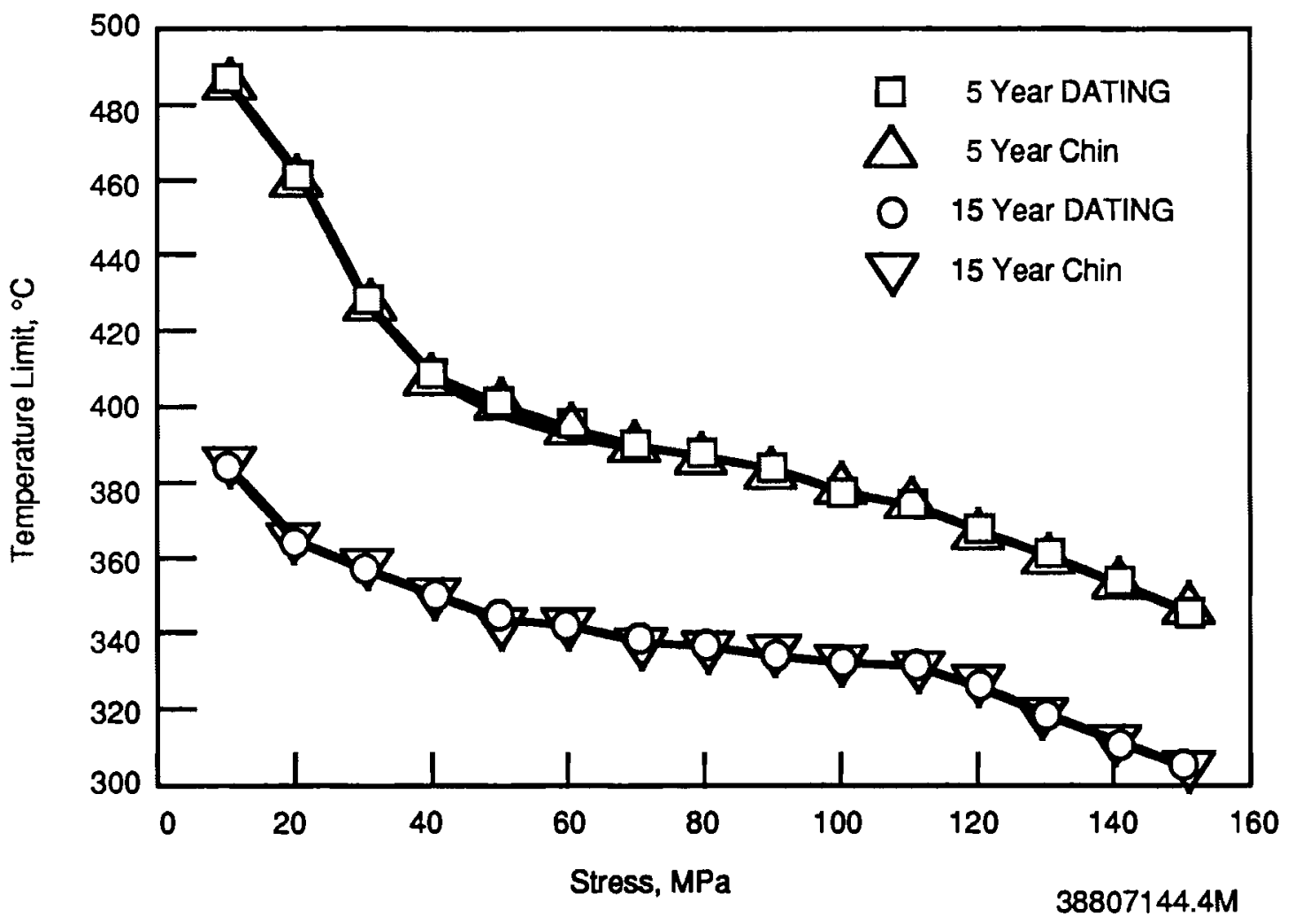

FIGURE 6. Temperature Limit Comparing Results of DATING and Chin et al. (1986) 


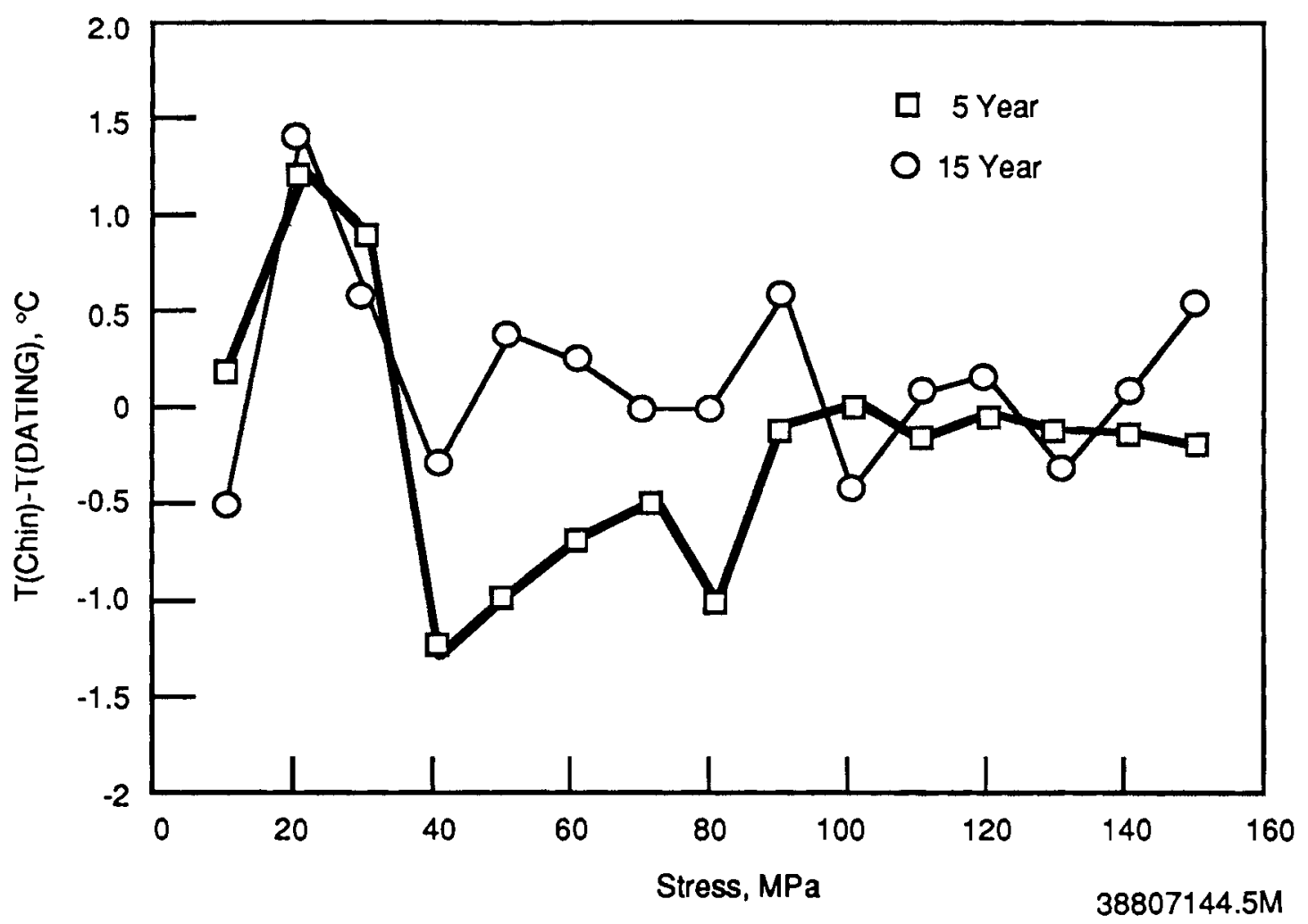

FIGURE 7. Difference in Temperature Limit Between DATING and Chin et al. (1986) 
TABLE 3. Example Output of Temperature/Stress Limit

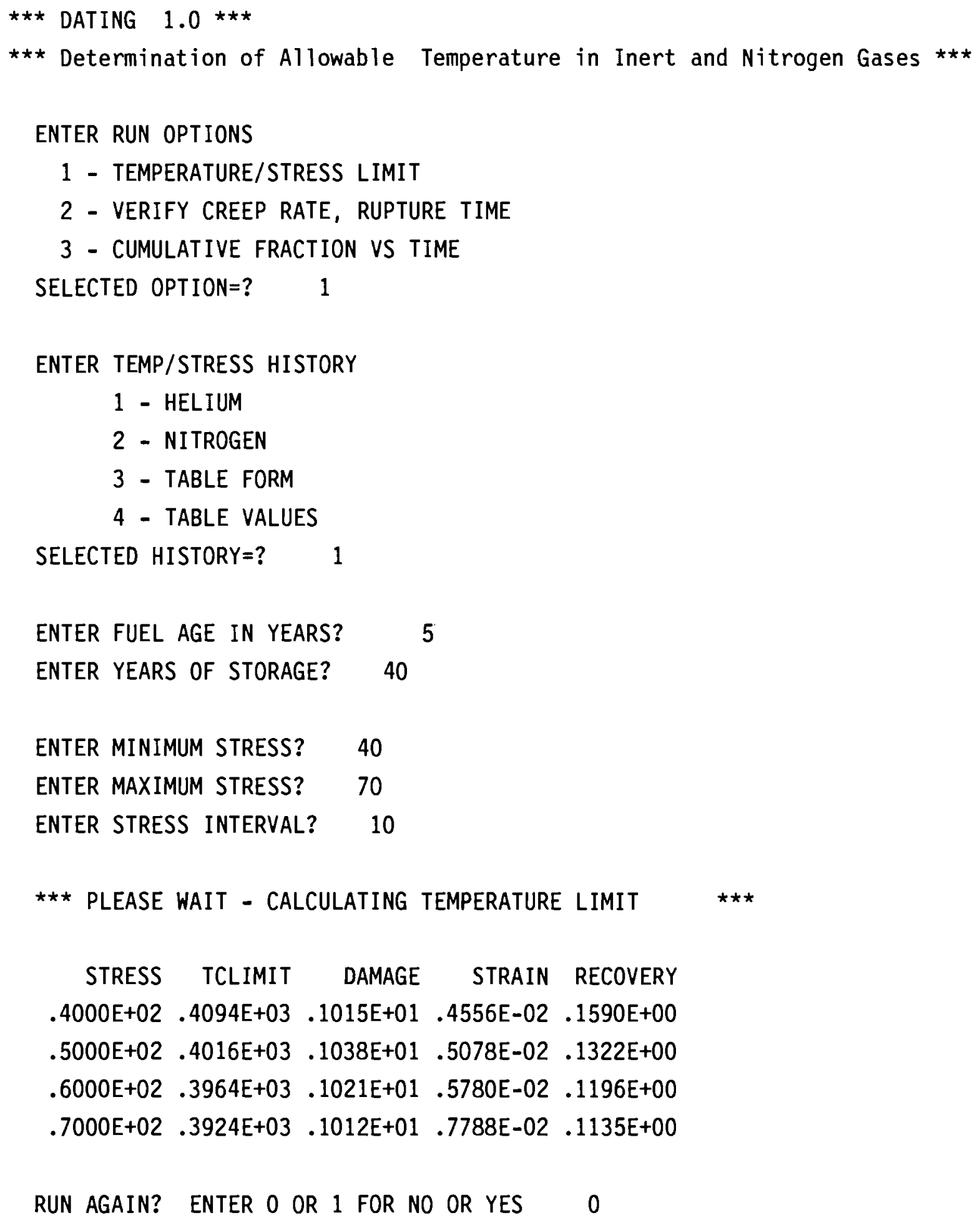

RUN AGAIN? ENTER 0 OR 1 FOR NO OR YES 0 
TABLE 4. Example Output of Verify Creep Rate, Rupture Time

DATING $1.0 \star \star \star$

Determination of Allowable Temperature in Inert and Nitrogen Gases $\star \star \star$

ENTER RUN OPTIONS

1 - TEMPERATURE/STRESS LIMIT

2 - VERIFY CREEP RATE, RUPTURE TIME

3 - CUMULATIVE FRACTION VS TIME

SELECTED OPTION=? 2

ENTER TEMPERATURE OR STRESS RANGE

1 - VARY TEMPERATURE; CONSTANT STRESS

2 - VARY TEMPERATURE; CONSTANT LOG(STRESS/EM)

3 - VARY STRESS; CONSTANT TEMPERATURE

4 - VARY LOG(STRESS/EM); CONSTANT TEMPERATURE

SELECTED OPTION FOR RANGE=? 1

ENTER CONSTANT STRESS, MPA? 50

ENTER MINIMUM TEMPERATURE, C? 300

ENTER MAXIMUM TEMPERATURE, C? 400

ENTER TEMPERATURE INTERVAL, C? 25

CREEP RATES $1 /$ SEC

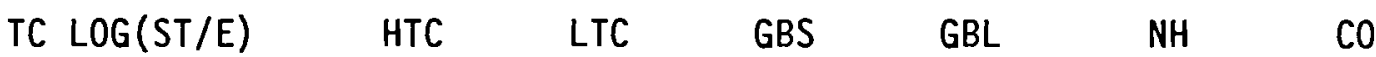
ATHERMAL

$300-.737 E+01 \quad .769 E-13 \quad .409 E-13 \quad .126 E-11 \quad .000 E+00 \quad .255 E-16 \quad .121 E-12$ $.000 \mathrm{E}+00$

$325-.735 E+01 \quad .707 E-12 \quad .211 E-12 \quad .569 E-11 \quad .000 E+00 \quad .219 E-15 \quad .540 E-12$ $.000 \mathrm{E}+00$

$350-.734 \mathrm{E}+01 \quad .548 \mathrm{E}-11 \quad .961 \mathrm{E}-12 \quad .229 \mathrm{E}-10 \quad .000 \mathrm{E}+00 \quad .158 \mathrm{E}-14 \quad .213 \mathrm{E}-11$ $.000 \mathrm{E}+00$

$\begin{array}{lllllllll}375 & -.732 E+01 & .364 E-10 & .393 E-11 & .825 E-10 & .000 E+00 & .979 E-14 & .756 E-11\end{array}$ $.000 \mathrm{E}+00$ 
TABLE 4. Continued

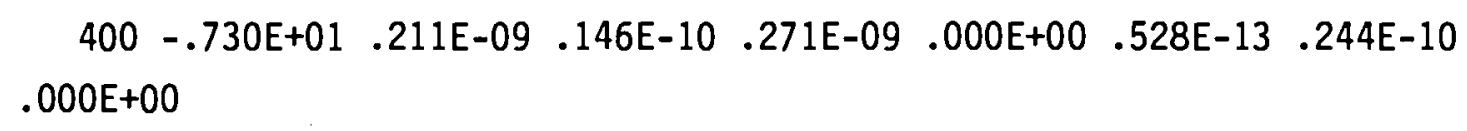

RUPTURE TIMES

$\begin{array}{rrrrr}\text { TC } & \text { TG } & \text { TP } & \text { CD } & \text { CP } \\ 300 & .132 E+12 & .554 E+12 & .318 E+11 & .163 E+12 \\ 325 & .291 E+11 & .122 E+12 & .712 E+10 & .359 E+11 \\ 350 & .725 E+10 & .304 E+11 & .180 E+10 & .894 E+10 \\ 375 & .201 E+10 & .842 E+10 & .509 E+09 & .248 E+10 \\ 400 & .612 E+09 & .257 E+10 & .158 E+09 & .755 E+09\end{array}$

SUMMARY OF DOMINANT CREEP AND RUPTURE MECHANISMS

TC CREEP RATE RUPTURE TIME MECHANISM

$300 \quad .126 \mathrm{E}-11 \quad .318 \mathrm{E}+11 \quad 33$

$325 \quad .569 \mathrm{E}-11 \quad .712 \mathrm{E}+10 \quad 33$

$350 \quad .229 \mathrm{E}-10 \quad .180 \mathrm{E}+10 \quad 33$

$\begin{array}{llll}375 & .825 \mathrm{E}-10 \quad .509 \mathrm{E}+09 & 33\end{array}$

$400 \quad .271 \mathrm{E}-09 \quad .158 \mathrm{E}+09 \quad 33$

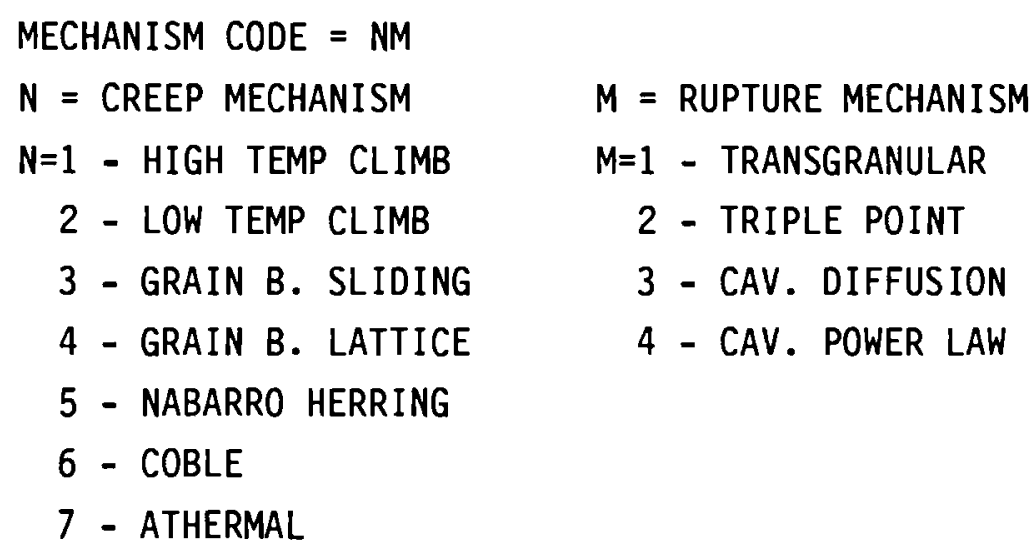

RUN AGAIN? ENTER 0 OR 1 FOR NO OR YES 0 
The example of cumulative-damage fraction, as a function of storage time in years, is shown in Table 5. The initial fuel age, temperature, and stress are 5 years, $380{ }^{\circ} \mathrm{C}$, and $70 \mathrm{MPa}$, respectively. The data are output at intervals of two years. An example of calculated cumulative fraction is plotted in Figure 8.

\section{DPLOT BASICA ROUTINE}

The output of the cumulative damage-fraction calculation, i.e., run option 3, can be plotted on the screen using the OPLOT.BAS program. The user must have the necessary BASICA files on the disk being used. DPLOT.BAS reads the DATING.OUT file after running option 3 for only one case. If more than one case is run, DPLOT.BAS only reads the output from the first case. Options for plotting are displayed on the screen. The parameter TH defines the thermal history option used for the calculation. Figure 8 is an example plot using DPLOT.BAS. 
IABLE 5. Example Output of Cumulative Fraction Versus Time

* DATING $1.0 * \star \star$

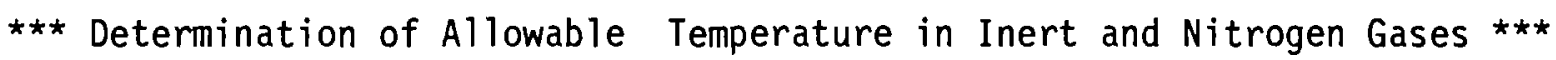

ENTER RUN OPTIONS

1 - TEMPERATURE/STRESS LIMIT

2 - VERIFY CREEP RATE, RUPTURE TIME

3 - CUMULATIVE FRACTION VS TIME

SELECTED OPTION=? 3

ENTER TEMP/STRESS HISTORY

1 - HELIUM

2 - NITROGEN

3 - TABLE FORM

4 - TABLE VALUES

SELECTED HISTORY $=? \quad 2$

ENTER FUEL AGE IN YEARS? 10

ENTER YEARS OF STORAGE? 40

INPUT TOTAL TIME STEPS FOR OUTPUT? 10

ENTER TMAX C? 390

ENTER MAX STRESS MPA? 35

$\begin{array}{rrrrrr}\text { YEARS } & \text { DAMAGE } & \text { STRAIN } & \text { RECOVERY } & \text { TEMPC } & \text { STRESS } \\ .100 E+02 & .000 E+00 & .000 E+00 & .100 E+00 & .390 E+03 & .350 E+02 \\ .140 E+02 & .157 E+01 & .618 E-02 & .164 E+00 & .369 E+03 & .339 E+02 \\ .180 E+02 & .208 E+01 & .856 E-02 & .174 E+00 & .354 E+03 & .331 E+02 \\ .220 E+02 & .232 E+01 & .973 E-02 & .177 E+00 & .343 E+03 & .325 E+02 \\ .260 E+02 & .246 E+01 & .104 E-01 & .178 E+00 & .334 E+03 & .321 E+02 \\ .300 E+02 & .255 E+01 & .108 E-01 & .178 E+00 & .327 E+03 & .317 E+02 \\ .340 E+02 & .261 E+01 & .111 E-01 & .179 E+00 & .321 E+03 & .314 E+02 \\ .380 E+02 & .265 E+01 & .113 E-01 & .179 E+00 & .316 E+03 & .311 E+02\end{array}$


TABLE 5. Cont inued

$\begin{array}{llllll}.420 E+02 & .268 E+01 & .114 E-01 & .179 E+00 & .311 E+03 & .309 E+02 \\ .460 E+02 & .271 E+01 & .115 E-01 & .179 E+00 & .307 E+03 & .306 E+02 \\ .500 E+02 & .273 E+01 & .116 E-01 & .179 E+00 & .304 E+03 & .305 E+02 \\ \\ \text { INTEGRATION WAS COMPLETED US ING } \\ \text { TIME STEPS }=50 \quad \text { FIRST STEP(SEC) }= \\ .127 E+09\end{array}$

RUN AGAIN? ENTER O OR 1 FOR NO OR YES 0 


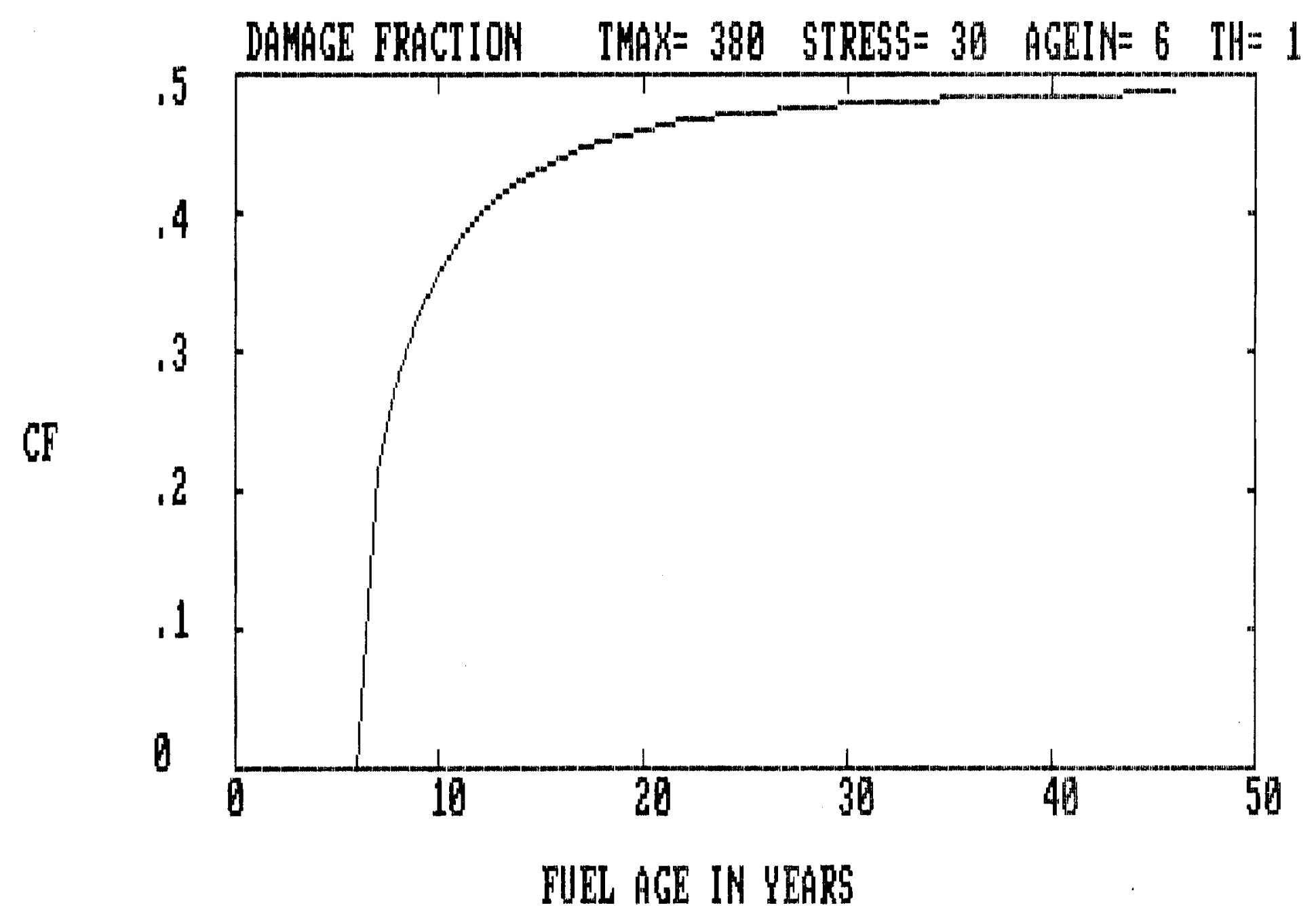

\section{ENTER PLOT TYPE: CF, ST, REC, TC, TABLE, END?}

FIGURE 8. Example Plot of Cumulative Damage-Fraction Versus Time 



\section{ACKNOWLEDGMENTS}

This work was supported by the U.S. Department of Energy (DOE), Office of Civilian Radioactive Waste Management, through the Commercial Spent Fuel Management Division of the DOE Richland Operations Office. The project was managed by the PNL Commercial Spent Fuel Management Program. Special recognition is given to D. R. Rector, J. 0. Barner, and W. C. Morgan for assistance with peer review and to B. A. Chin for helpful discussions. 


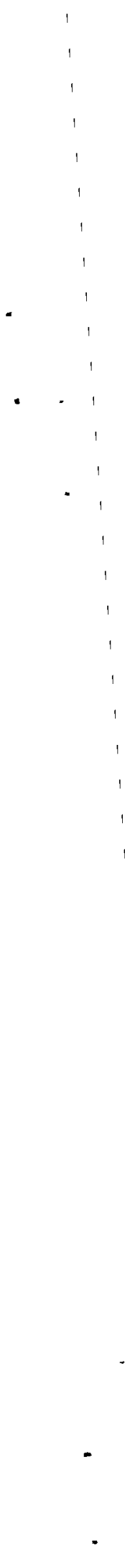




\section{REFERENCES}

Chin, B. A., M. A. Khan, and J. Tarn. 1986. Deformation and Fracture Map Methodology for Predicting Cladding Behavior During Dry Storage. PNL-5998, Pacific Northwest Laboratory, Richland, Washington.

Cunningham, M. E., E. P. Simonen, R. T. Alleman, I. S. Levy, R. F. Hazelton, and E. R. Gilbert. 1987. Control of Degradation of Spent LWR Fuel During Dry Storage in Inert Atmosphere. PNL-6364, Pacific Northwest Laboratory, Richland, Washington.

Hindmarsh, A. C. 1974. GEAR: Ordinary Differential Equation System Solver. Lawrence Livermore Laboratory Report UCID-30001, Rev. 3, Livermore, California.

Levy, I. S., B. A. Chin, E. P. Simonen, C. E. Beyer, E. R. Gilbert, and A. B. Johnson, Jr. 1987. Recommended Temperature Limits for Dry Storage of Spent Light Water Reactor Zircaloy-clad Fuel rods in Inert Gas. PNL-6189, Pacific Northwest Laboratory, Richland, Washington.

Steinberg, E., H. G. Weidinger, and A. Schaa. 1984. "Analytical Approaches and Experimental Verification to Describe the Influence of Cold Work and Heat Treatment on the Mechanical Properties of Zircaloy Cladding Tubes." Zirconium in the Nuclear Industry: Sixth International Symposium. ASTM STP 824, PP. 106-122. 


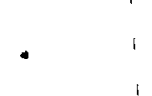

- 


\section{APPENDIX A}

\section{LISTING OF MAIN PROGRAM LINES}


-

- 


\section{LISTING OF MAIN PROGRAM LINES}

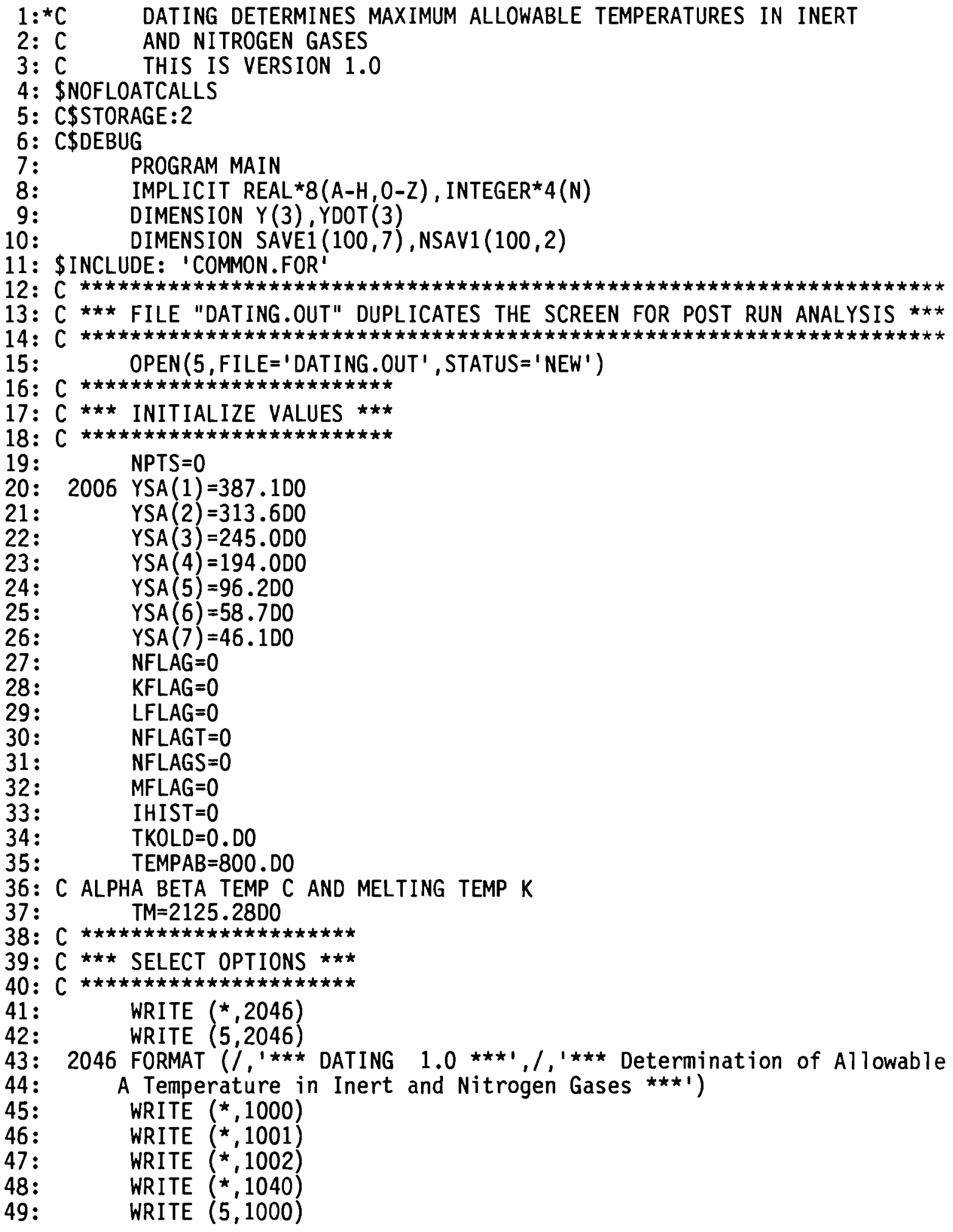




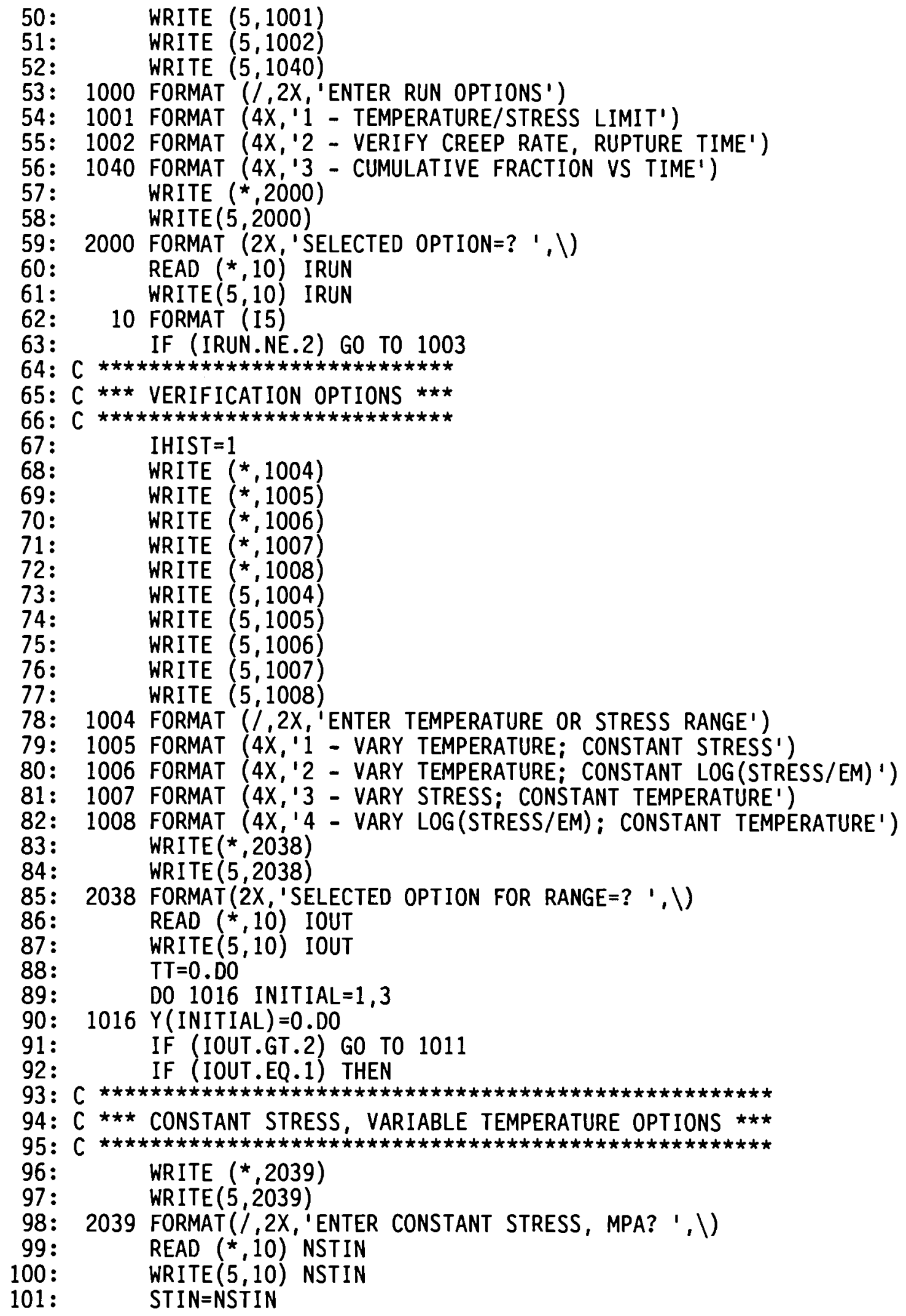




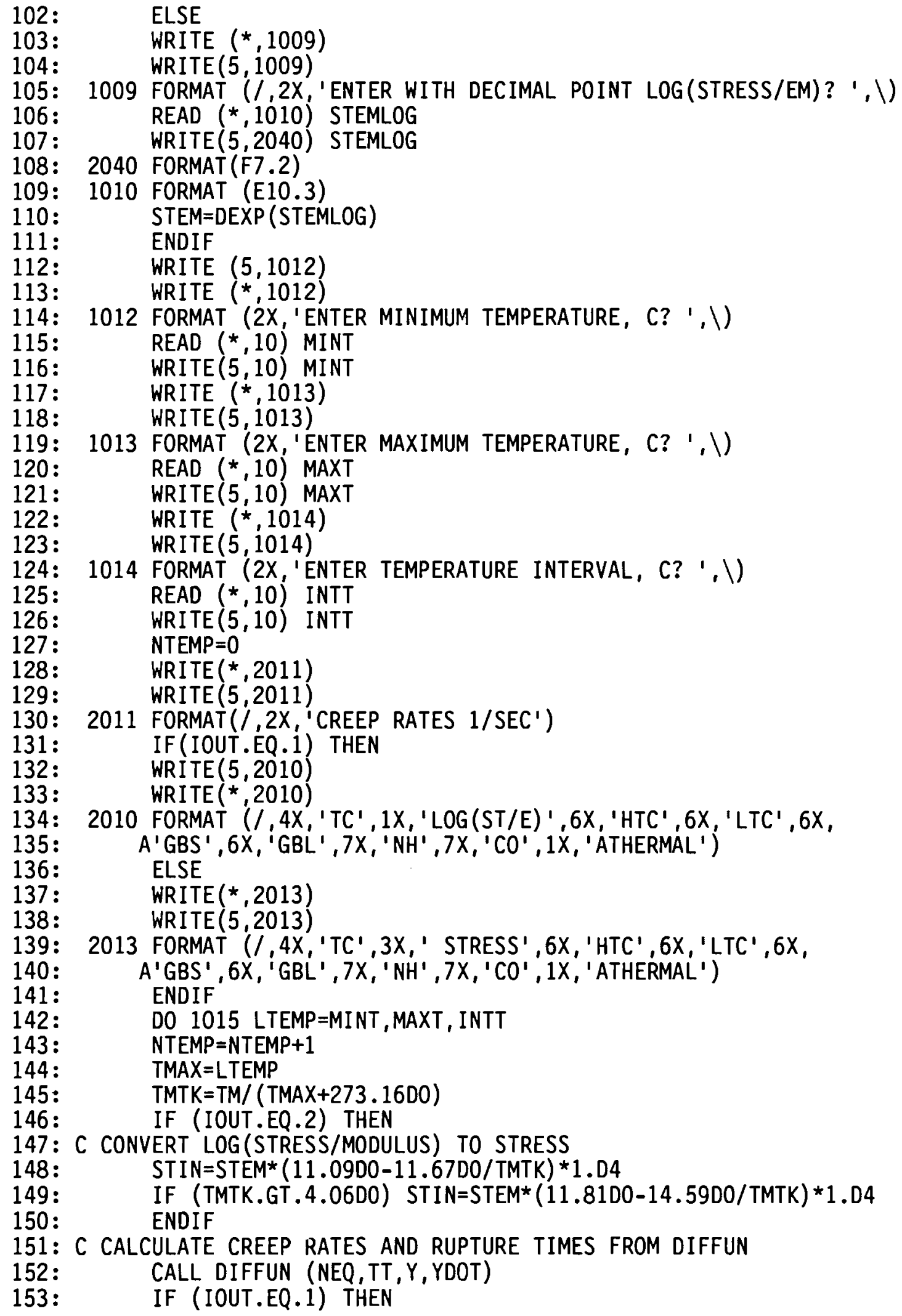


154: $\quad$ IF (TMTK.GT.4.06D0) THEN

155: $\quad$ STEMLOG $=$ LOG $($ STIN/ $((11.81 D 0-14.5900 /$ TMTK $) * 1 . D 4))$

156: $\quad$ ELSE

157: STEMLOG $=$ LOG $($ STIN/((11.09D0-11.67D0/TMTK $) * 1.04))$

158: $\quad$ ENDIF

159: $c$

160: $C$

161: $C$

162: $C$

163:

164:

165: $C$

166:

167:

168:

169:

170:

171:

172:

173:

174:

175:

176:

177:

178:

179:

180:

181:

182:

183:

184:

185 :

186:

187:

188:

189:

190:

191 :

192:

193:

194:

195:

196:

197:

198:

199:

200:

201:

202:

203:

204:

205:

$c *$

tatk

$\star \star *$ DIFFUSION RATE ER(4) IS NOT CALCULATED IN DIFFUN AND THERFORE

$\star \star \star$ IS ZERO IN THE OUTPUT BELOW. IT HAS BEEN INCLUDED AS

$\star \star \star$ A PARAMETER TO BE CONSISTENT WITH CONVENTIONS ESTABLISHED

$\star \star \star$ BY CHIN ET AL. PNL $-5998,1986$.

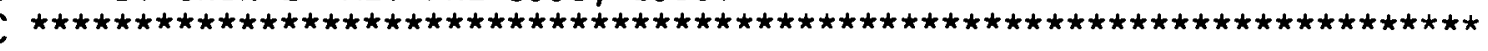

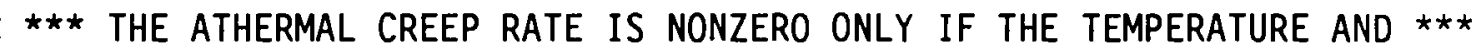

$\star \star \star$ STRESS HAVE VALUES WHICH CORRESPOND TO THE ATHERMAL REGION OF $\star \star \star \star$

$\star \star \star$ THE CREEP MECHANISM MAP

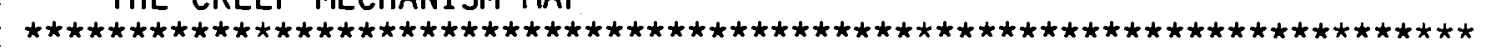

WRITE $(*, 1017)$ LTEMP, STEMLOG, ER(1), ER(2), ER(3), ER(4), ER(5),

$A \operatorname{ER}(6), \operatorname{ER}(7)$

WRITE $(5,1017)$ LTEMP, STEMLOG, ER(1), ER(2), ER(3), $\operatorname{ER}(4), \operatorname{ER}(5)$,

$A \operatorname{ER}(6), \operatorname{ER}(7)$

ELSE

WRITE (*,1017) LTEMP, STIN, ER(1), ER(2), ER(3), ER(4), ER(5),

$A \operatorname{ER}(6), \operatorname{ER}(7)$

WRITE $(5,1017) \operatorname{LTEMP}, \operatorname{STIN}, \operatorname{ER}(1), \operatorname{ER}(2), \operatorname{ER}(3), \operatorname{ER}(4), \operatorname{ER}(5)$,

$A \operatorname{ER}(6), \operatorname{ER}(7)$

1017 FORMAT (1X, I5, E10.3,7E9.3)

ENDIF

SAVE1 (NTEMP, 1) $=$ TF (1)

SAVE1 (NTEMP, 2) $=$ TF (2)

SAVE1 (NTEMP, 3) $=$ TF (3)

SAVE1 (NTEMP, 4) $=$ TF (4)

SAVE1 $($ NTEMP , 5) $=$ EDOTR

SAVE1 $($ NTEMP , 6) $=$ TMINR

NSAV1 (NTEMP, 1) $=$ MFLAG

1015 CONTINUE

WRITE $(*, 2012)$

WRITE $(5,2012)$

2012 FORMAT $(/, 2 X$, 'RUPTURE TIMES')

WRITE $(*, 2014)$

WRITE $(5,2014)$

2014 FORMAT (/,4X, 'TC' ,7X, 'TG' ,7X, 'TP' ,7X, 'CD',7X, 'CP')

DO 1019 LTEMP $=1$, NTEMP

WRITE $(*, 1018)$ NSAV1 $($ LTEMP , 2$)$,

A SAVE1 (ĹTEMP, 1), SAVE1 (LTEMP, 2), SAVE1 (LTEMP , 3)

B , SAVE1 (LTEMP, 4)

WRITE $(5,1018)$ NSAV1 (LTEMP, 2),

A SAVE1 (LTEMP, 1), SAVE1 (LTEMP, 2), SAVE1 (LTEMP, 3)

B , SAVE1 (LTEMP, 4)

1018 FORMAT (1X, I5, 4E9.3)

1019 CONTINUE

WRITE $(*, 2015)$ 
206: $\quad$ WRITE $(5,2015)$

207: 2015 FORMAT ( $/, 3 X$,' SUMMARY OF DOMINANT CREEP AND RUPTURE MECHANISMS')

208:

209:

210:

211:

212:

213:

214:

215:

216:

217:

218:

219:

221: $C$

222:

223:

224 :

225:

226:

227:

228:

229:

230:

231:

232:

233:

234:

235:

236:

237:

238:

239:

240:

241:

242:

243:

244:

245:

246:

247:

248:

249:

250 :

251:

252:

253:

254:

255:

256: WRITE $\left({ }^{\star}, 2016\right)$ WRITE $(5,2016)$

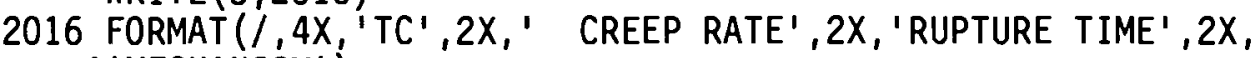
A'MECHANISM' $^{\prime}$ DO 2017 LTEMP $=1$, NTEMP WRITE $(*, 2018)$ NSAV1 (LTEMP , 2) , SAVE1 (LTEMP , 5) , SAVE1 (LTEMP , 6), ANSAV1 (LTEMP, 1) WRITE $(5,2018)$ NSAV1 (LTEMP , 2) , SAVE1 (LTEMP, 5) , SAVE1 (LTEMP, 6), ANSAV1 (LTEMP, 1)

2018 FORMAT (2X, I5, E13.3, E14.3, I11)

2017 CONTINUE

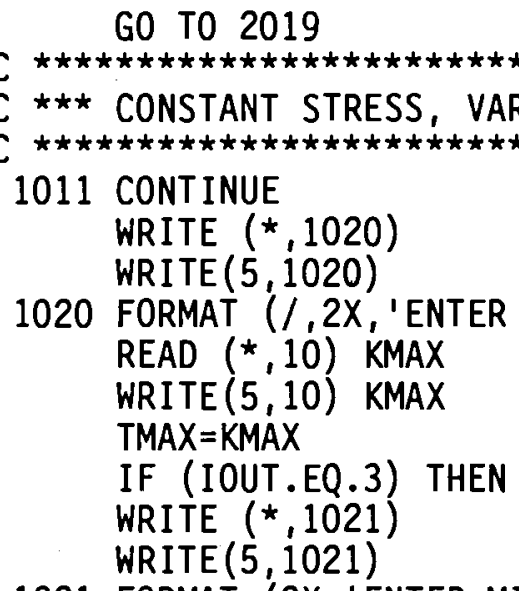




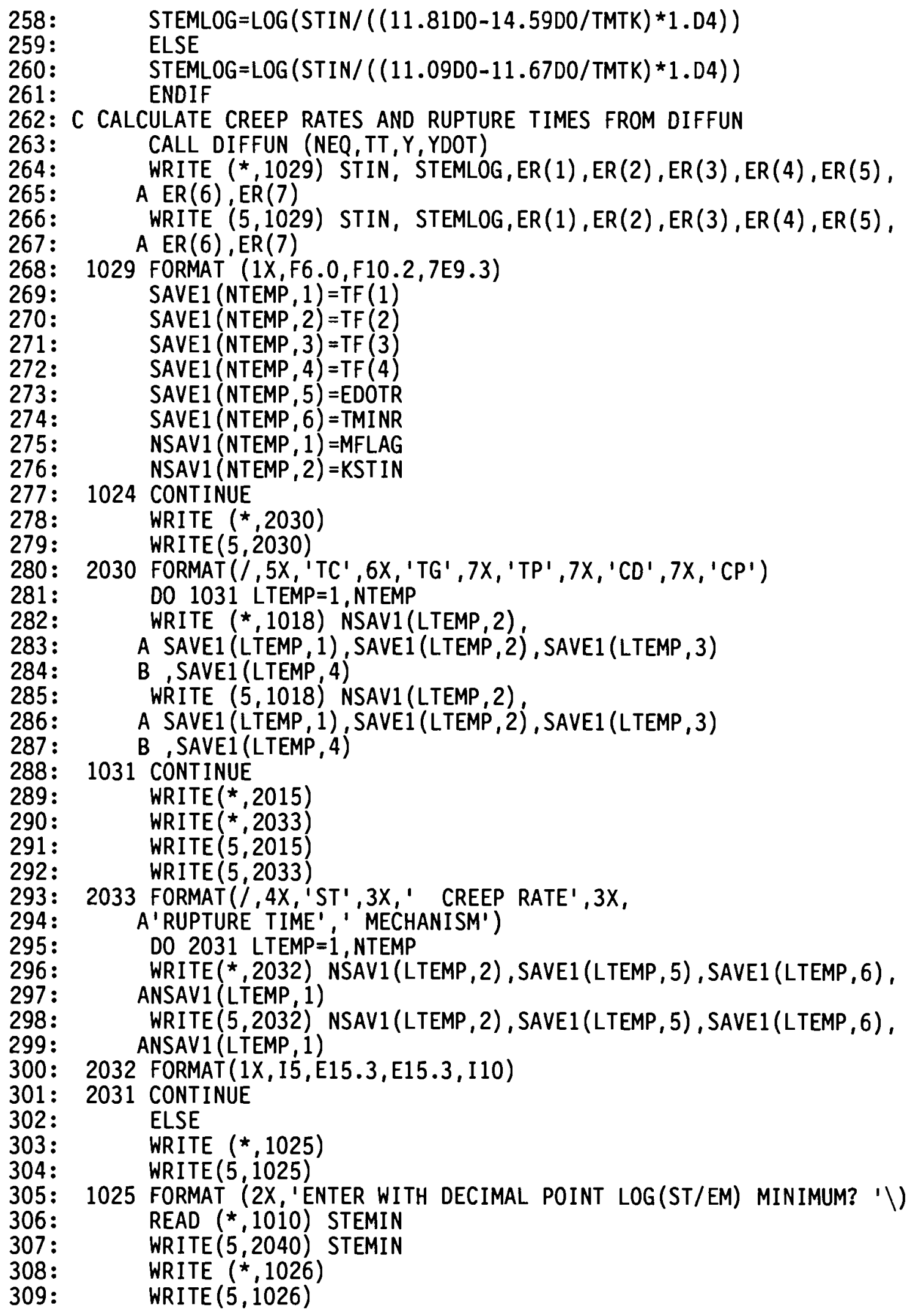




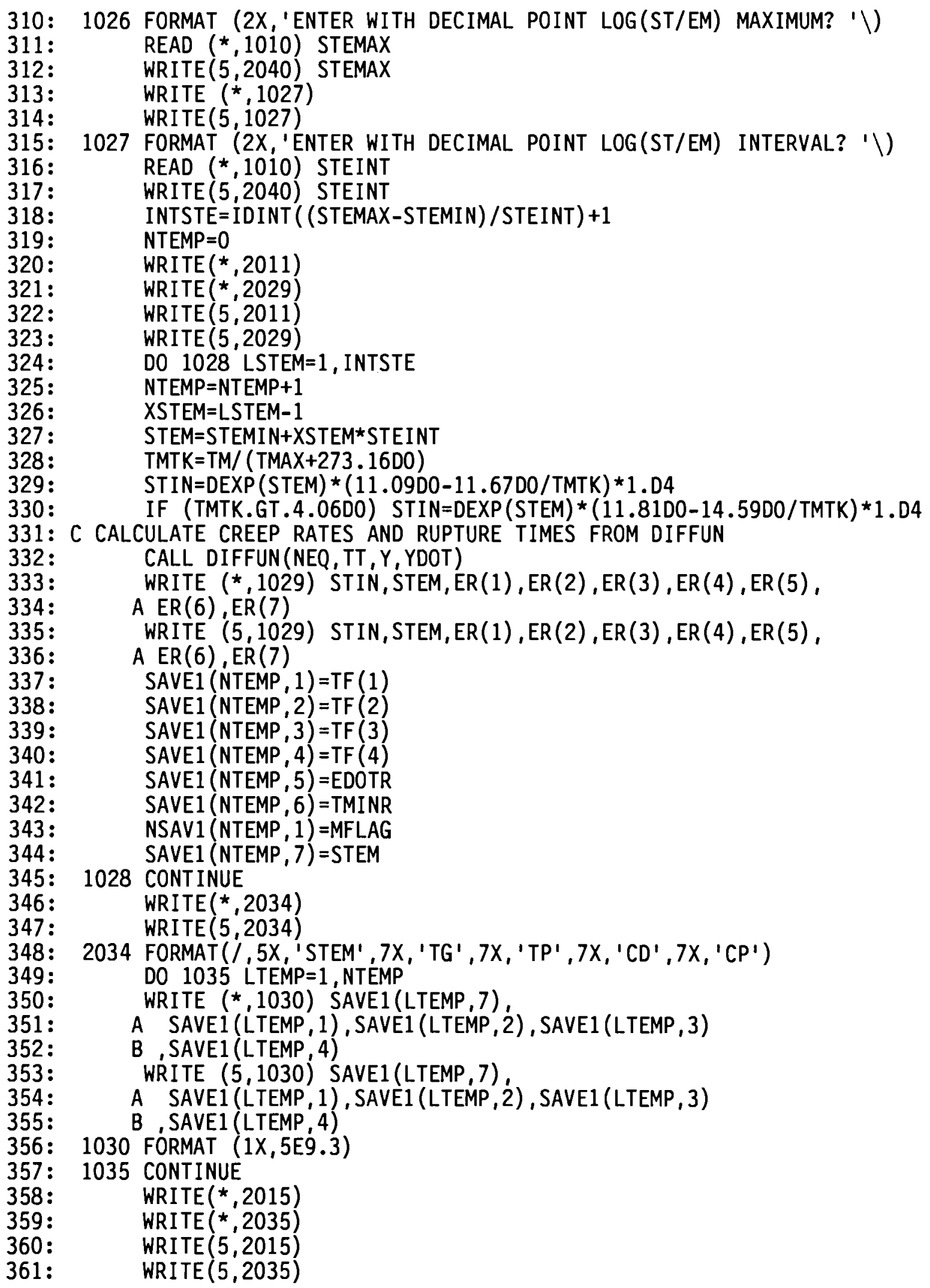




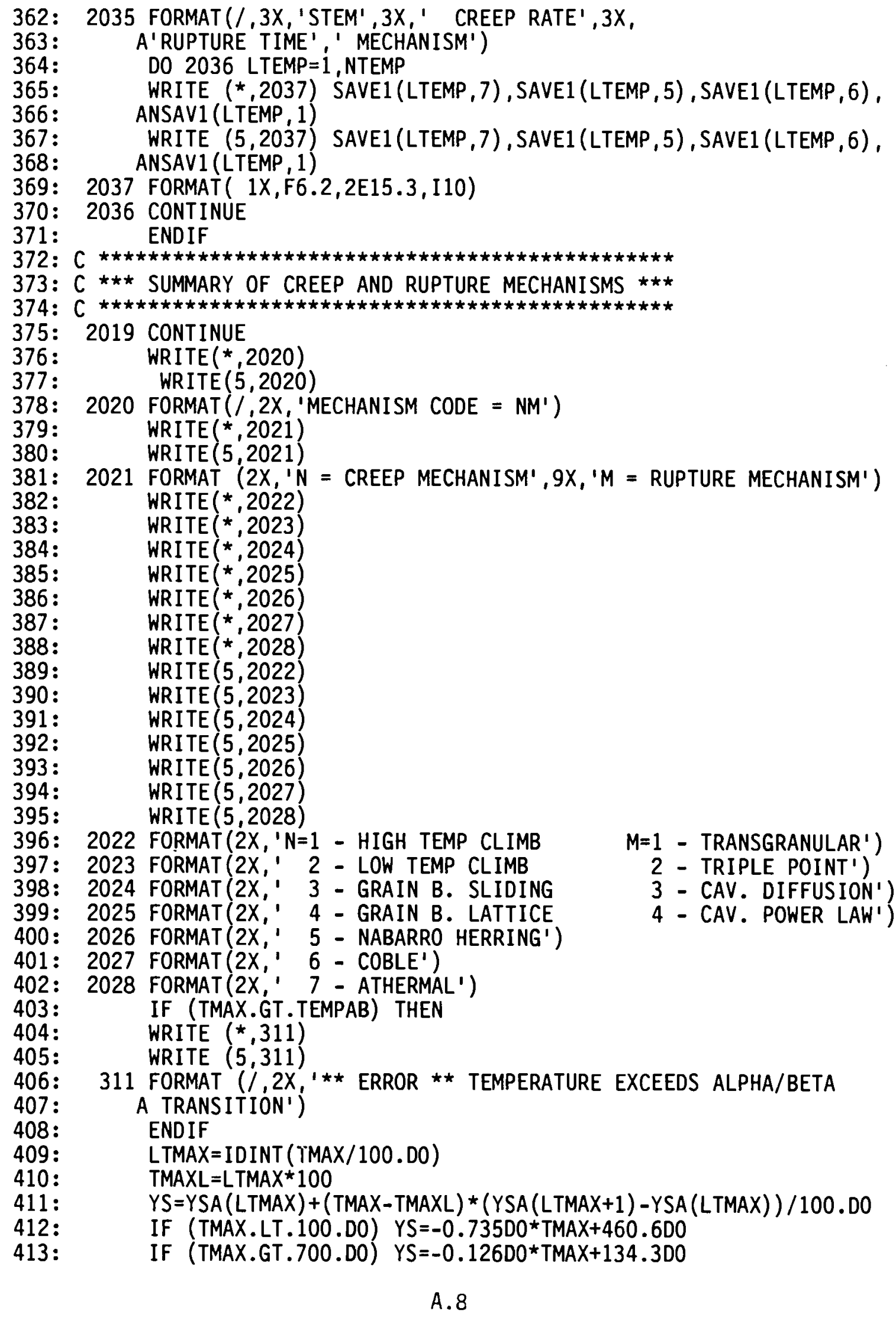

$M=1$ - TRANSGRANULAR'

2 - TRIPLE POINT')

3 - CAV. DIFFUSION')

4 - CAV. POWER LAW')

\section{A. 8}




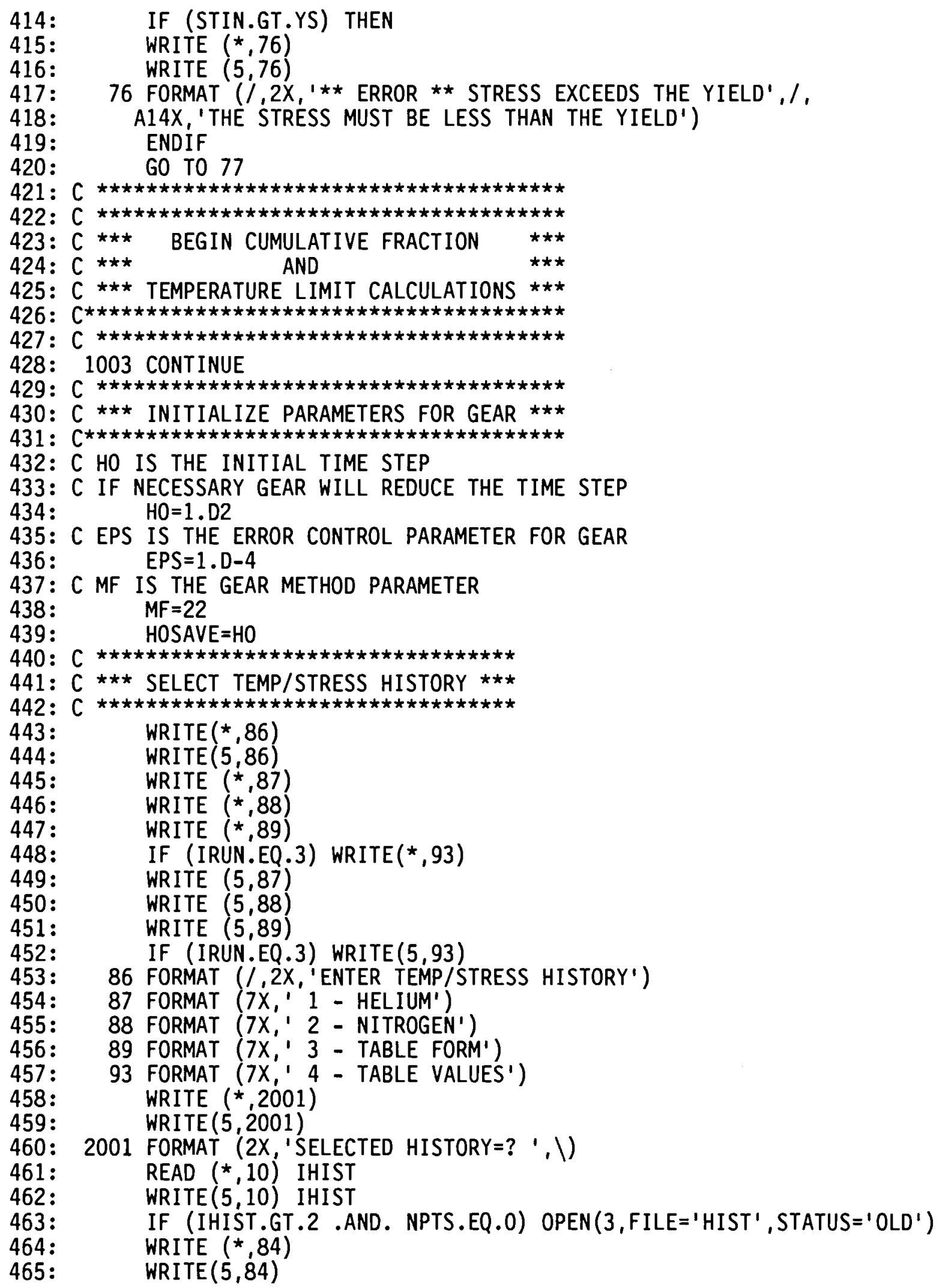




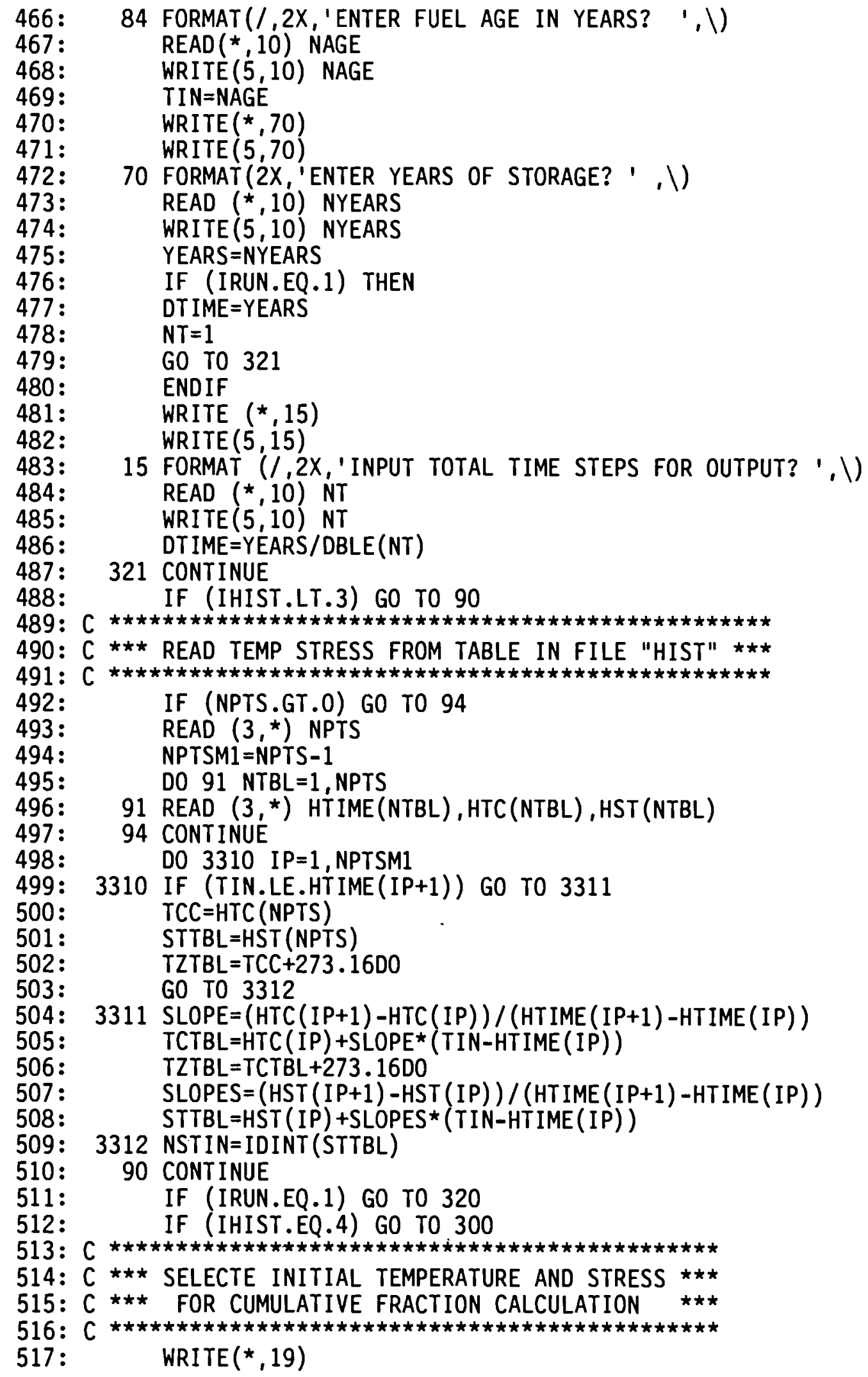




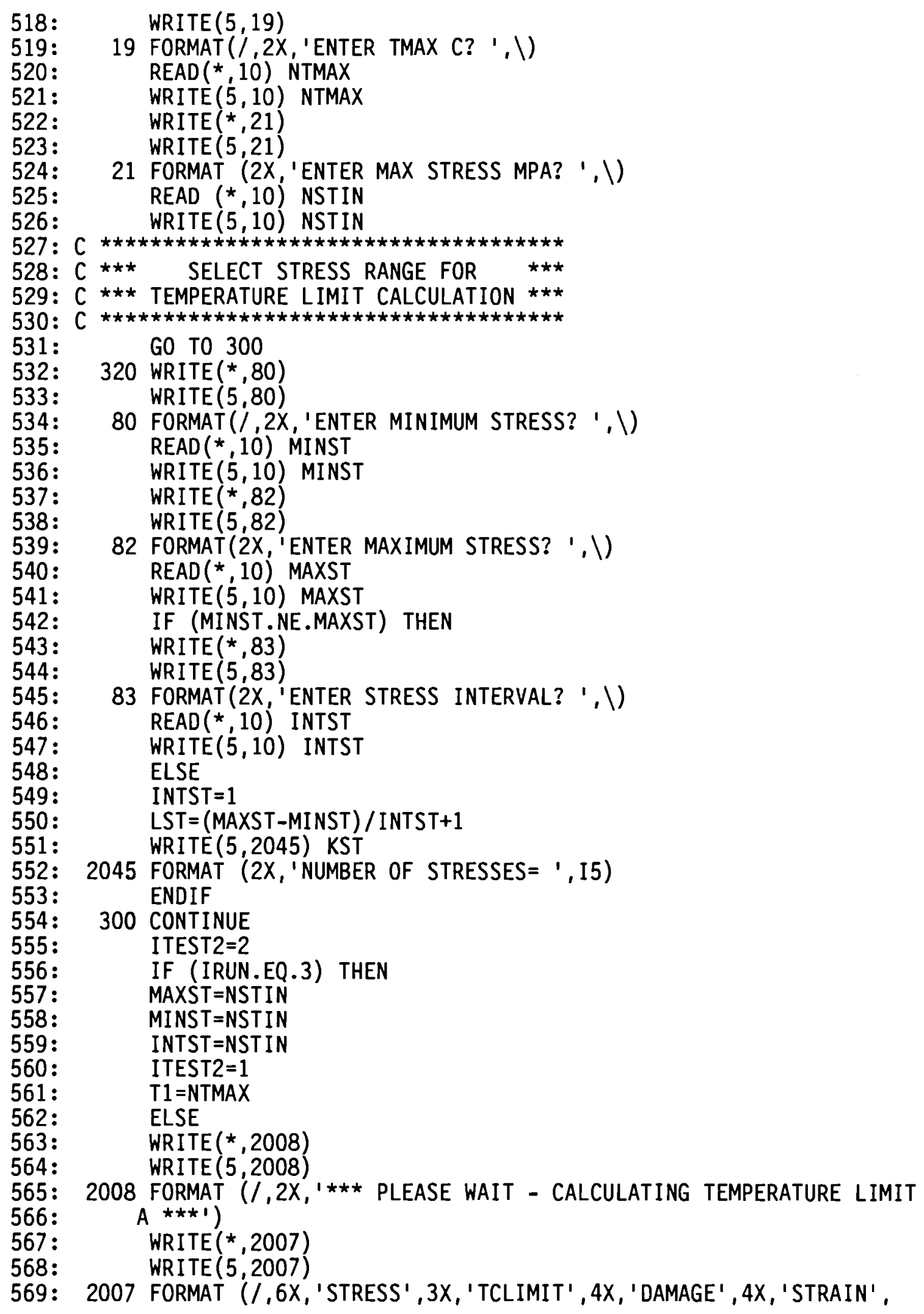

556 :

557:

558:

$559:$

560 :

$561:$

$562:$

$563:$

$564:$

$565:$

566 :

$567:$

$568:$

21 FORMAT (2X, 'ENTER MAX STRESS MPA? ' , $)$ READ $(*, 10)$ NSTIN 


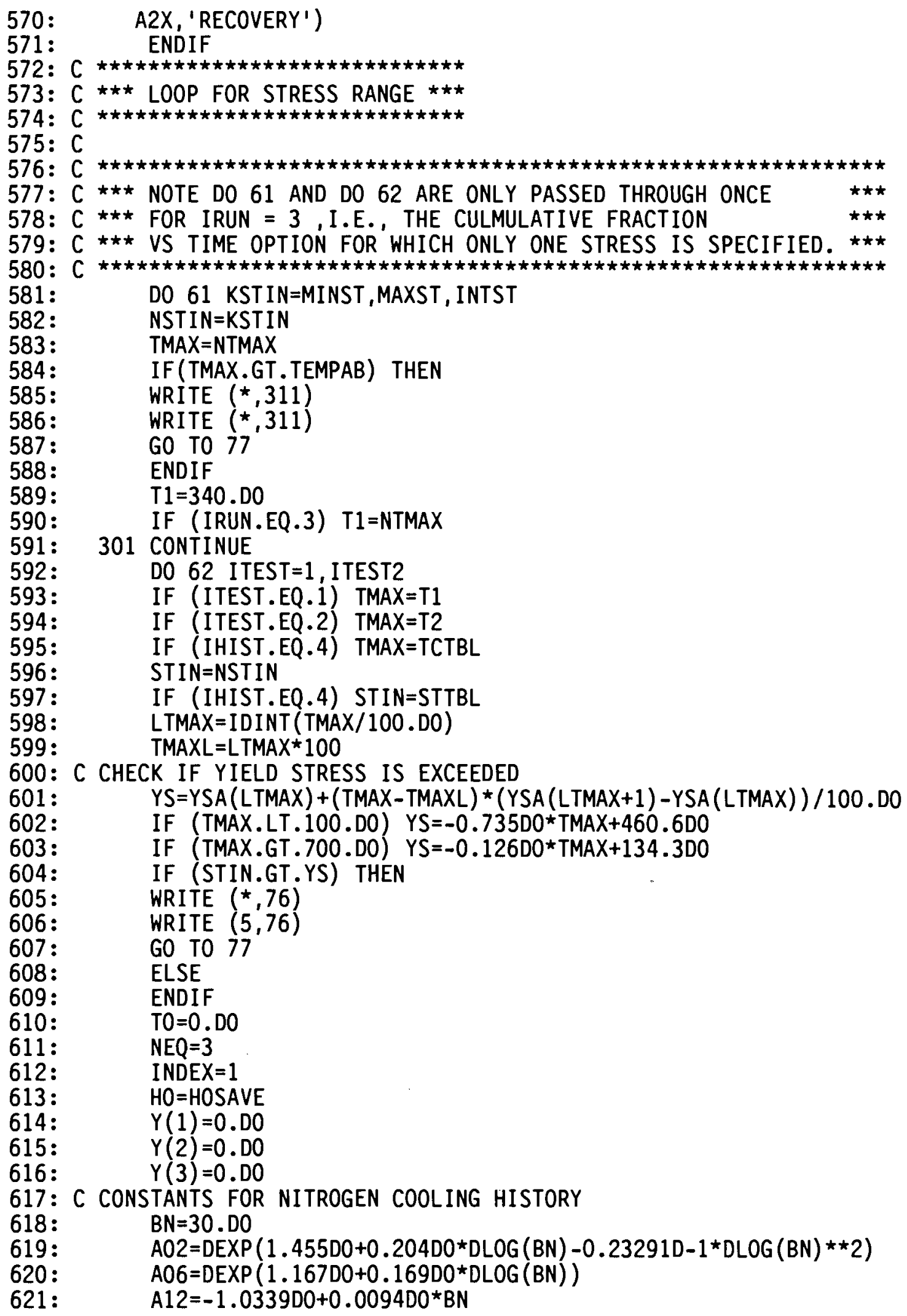




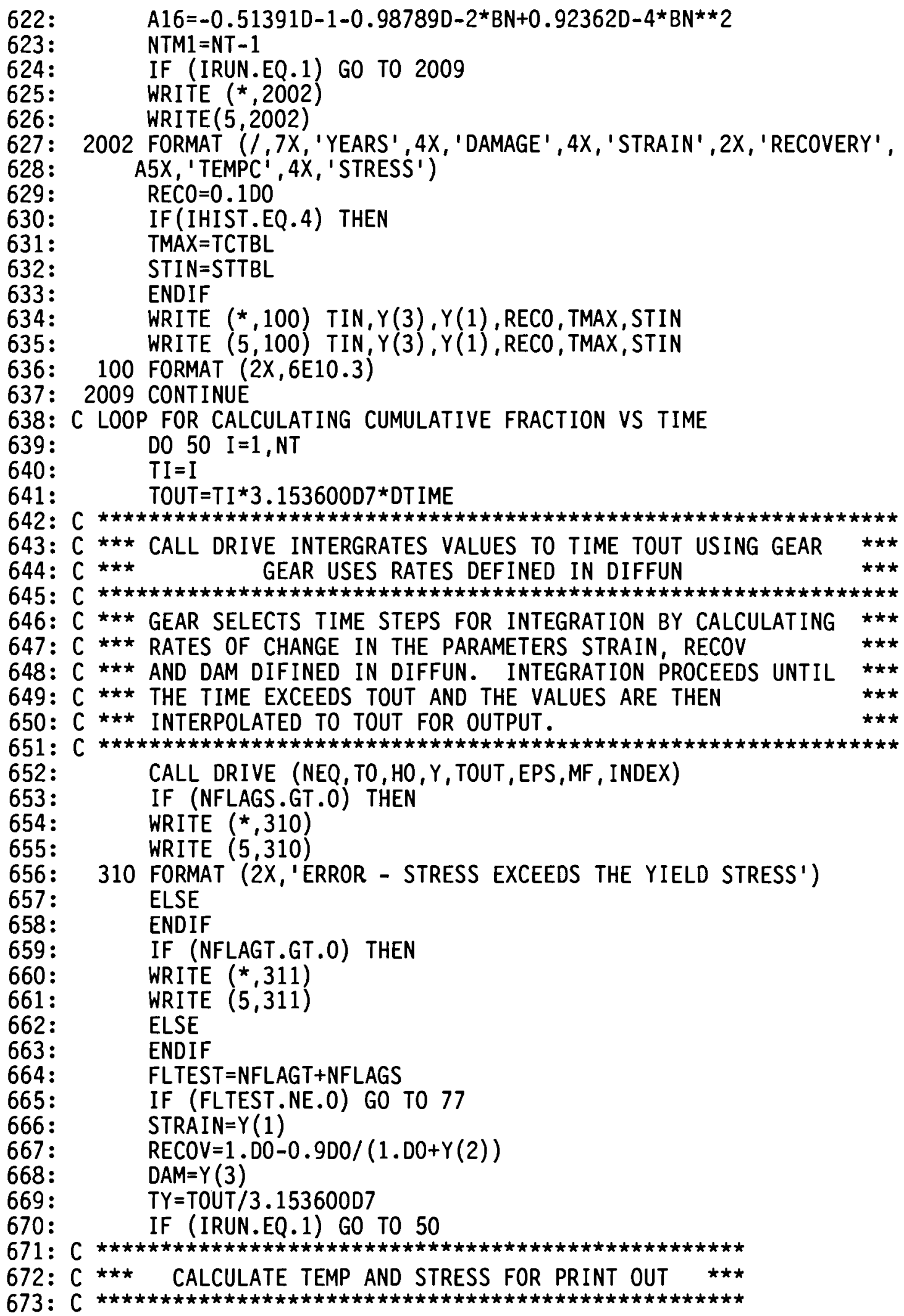




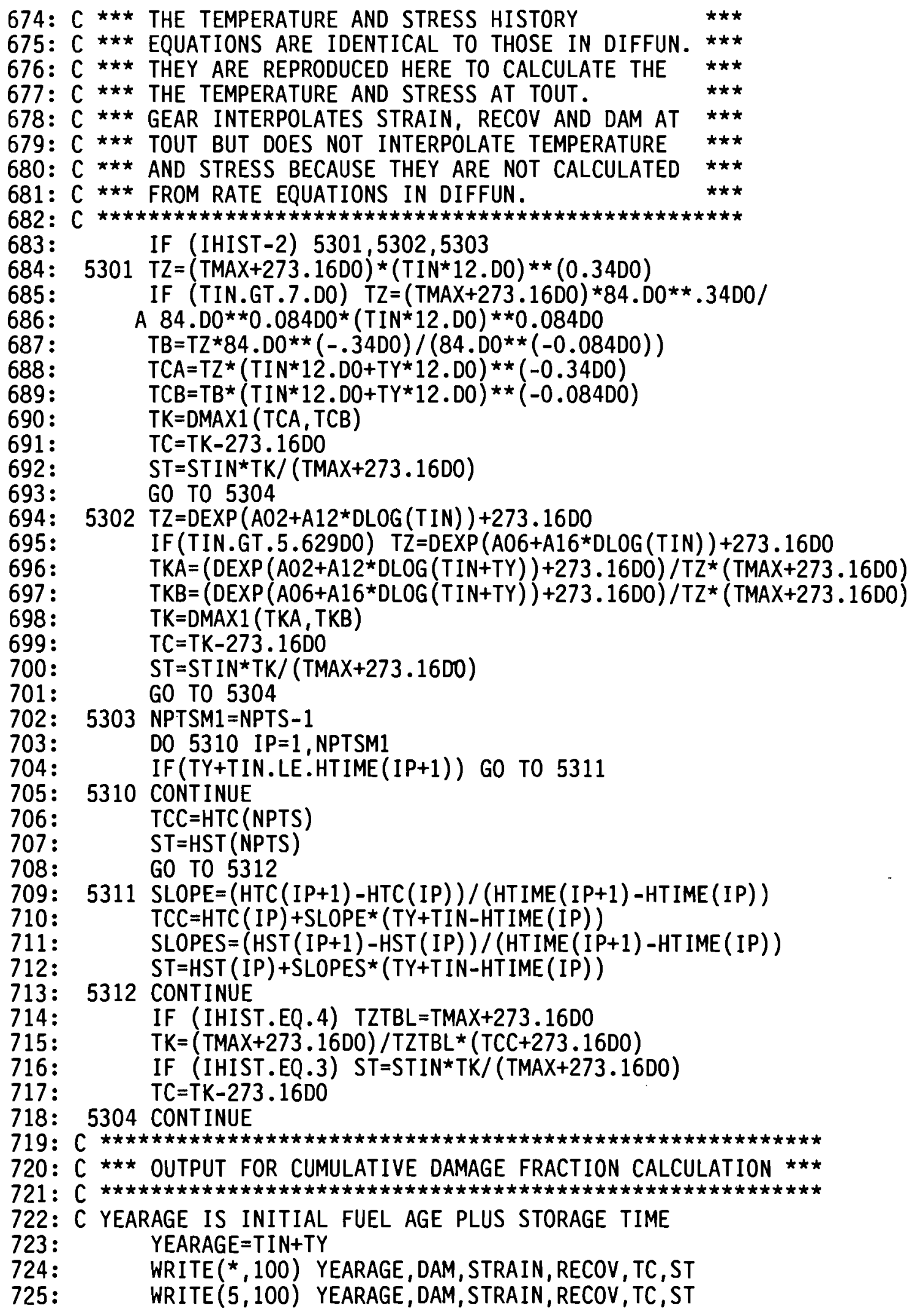




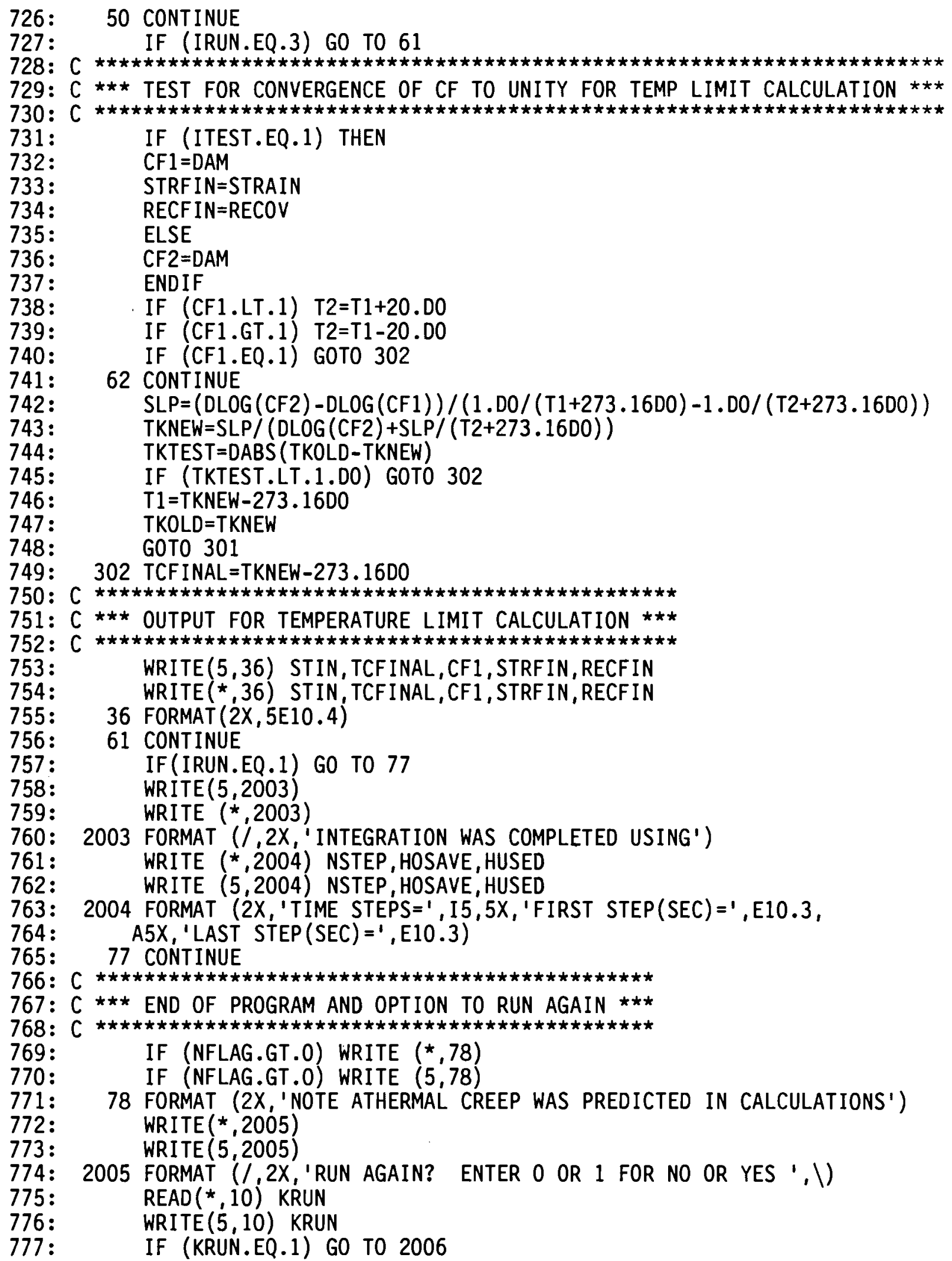


778: $C$

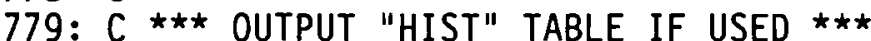

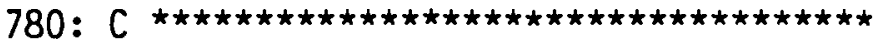

781: IF(IHIST.GT.2) THEN

782: WRITE $(*, 2041)$ NPTS

783: WRITE $(5,2041)$ NPTS

784: 2041 FORMAT (2X, 'THE FILE "HIST" WAS USED. NPTS=', I5)

785: WRITE $(*, 2042)$

786: WRITE $(5,2042)$

787: $\quad$ DO 2043 LPTS $=1$, NPTS

788: 2042 FORMAT $\left(2 X, 5 X\right.$, 'YEARS ', 4X, 'TEMP $C^{\prime}, 1 \mathrm{X}$, ' STRESS MPA')

789: WRITE $(*, 2044)$ HTIME(LPTS), HTC (LPTS), HST (LPTS)

790: WRITE $(5,2044)$ HTIME(LPTS), HTC(LPTS), HST (LPTS)

791: 2044 FORMAT $(2 X, 3 E 10.3)$

792: 2043 CONTINUE

793: ENDIF

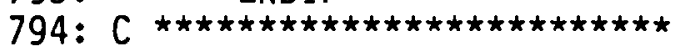

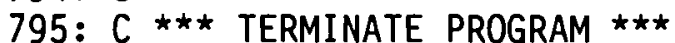

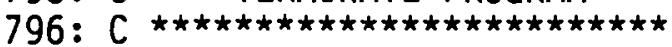

797: STOP

798: $\quad$ END 
APPENDIX B

LISTING OF DIFFUN SUBROUTINE 


\section{LISTING OF DIFFUN SUBROUTINE}

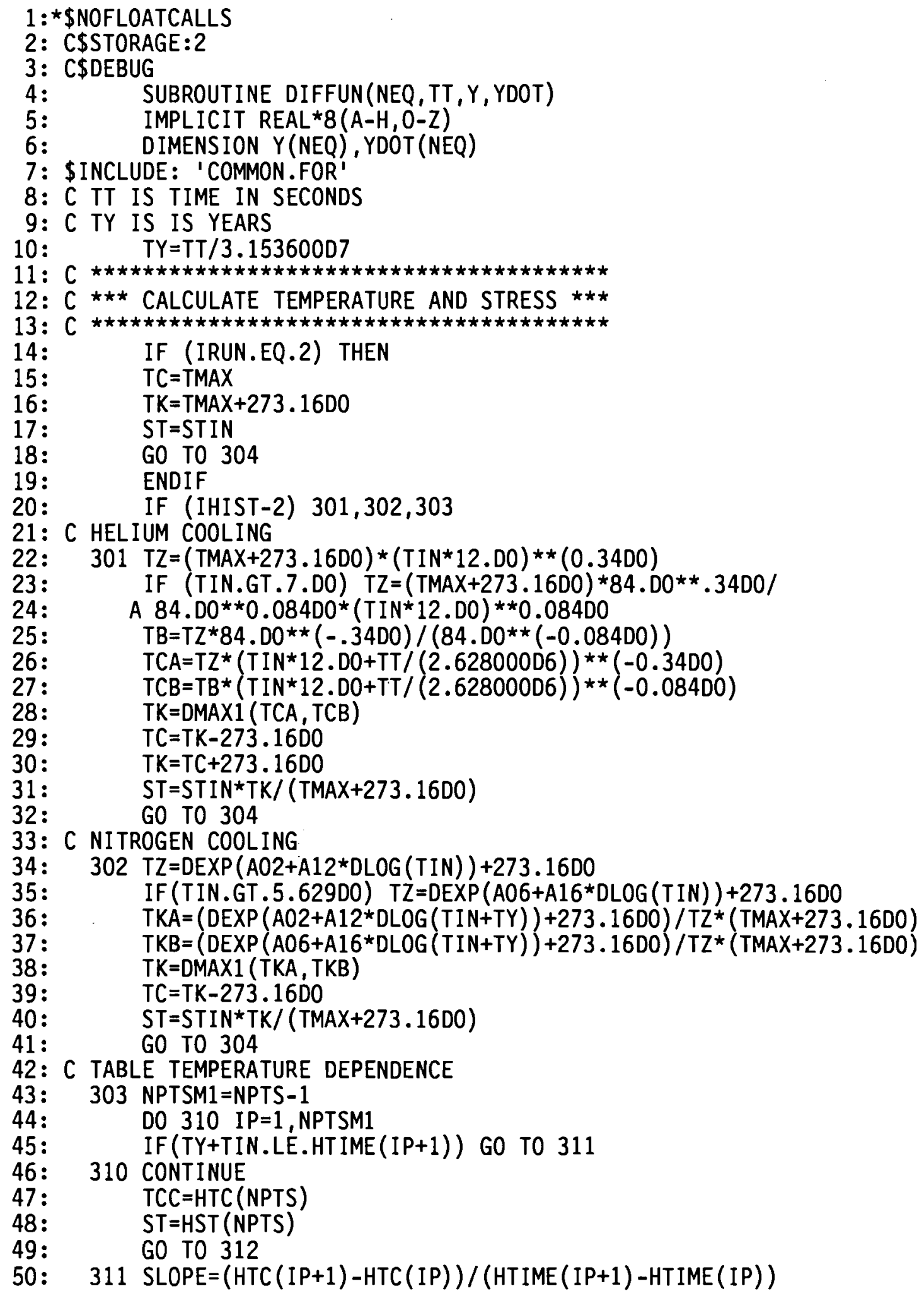




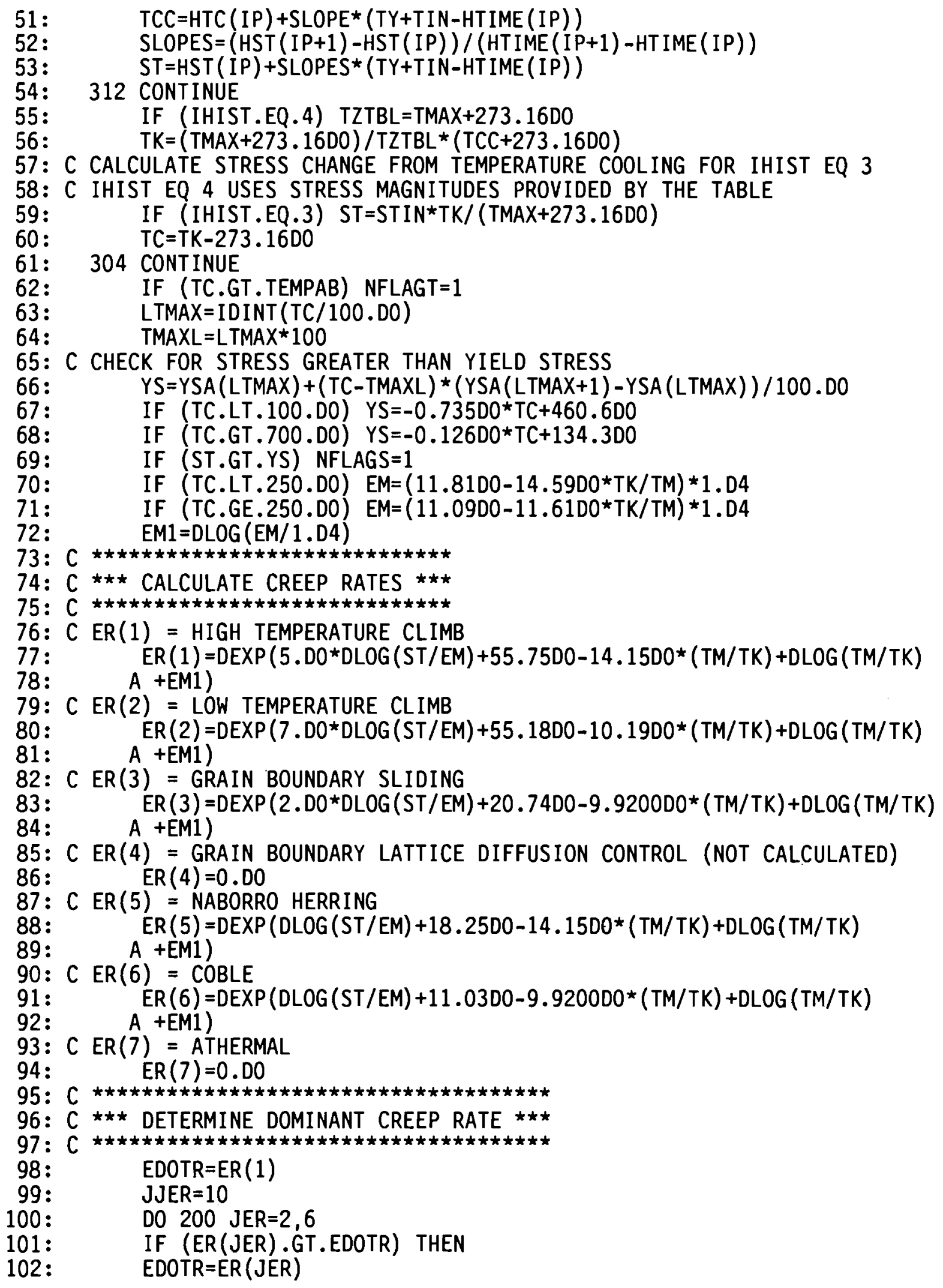




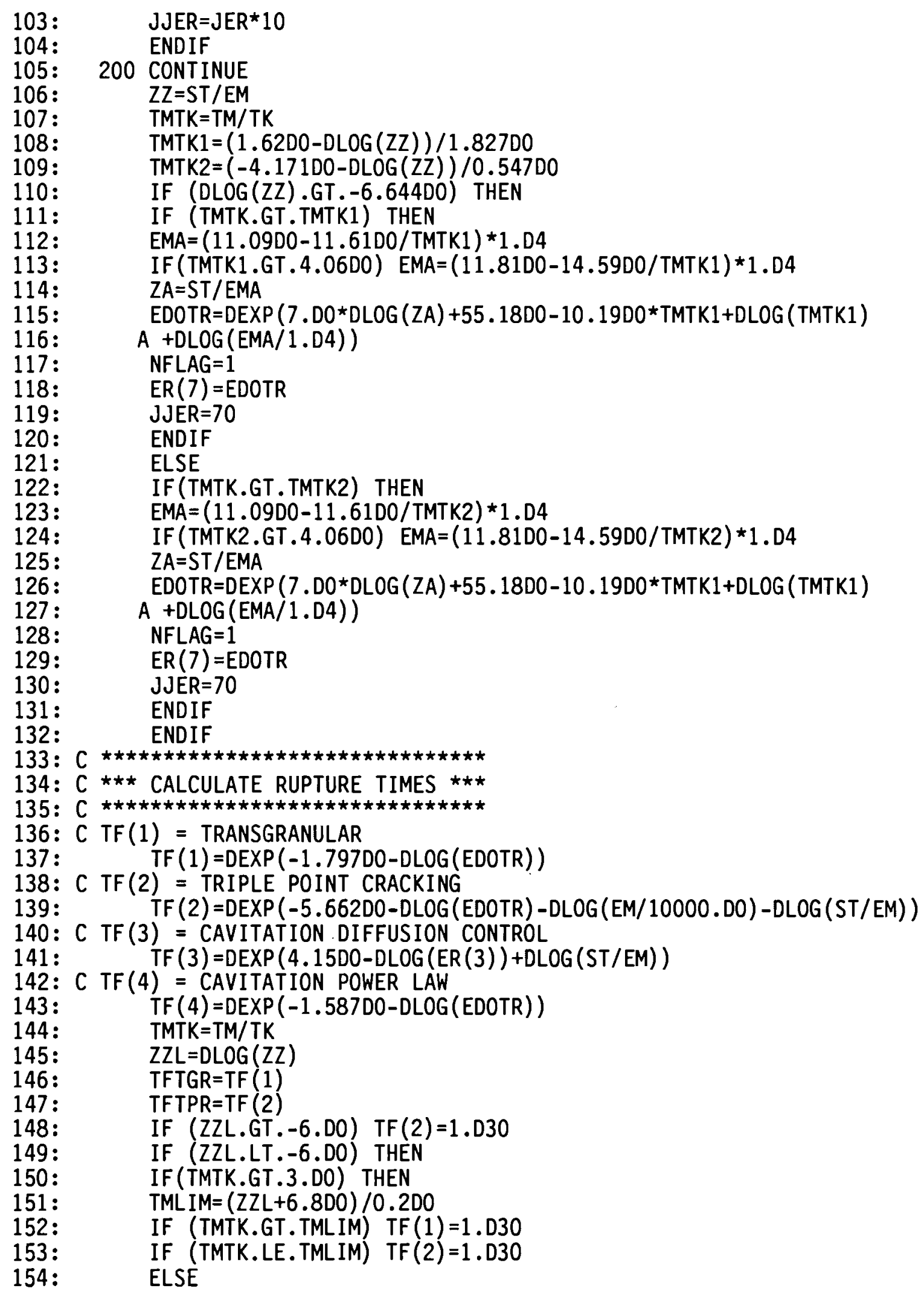




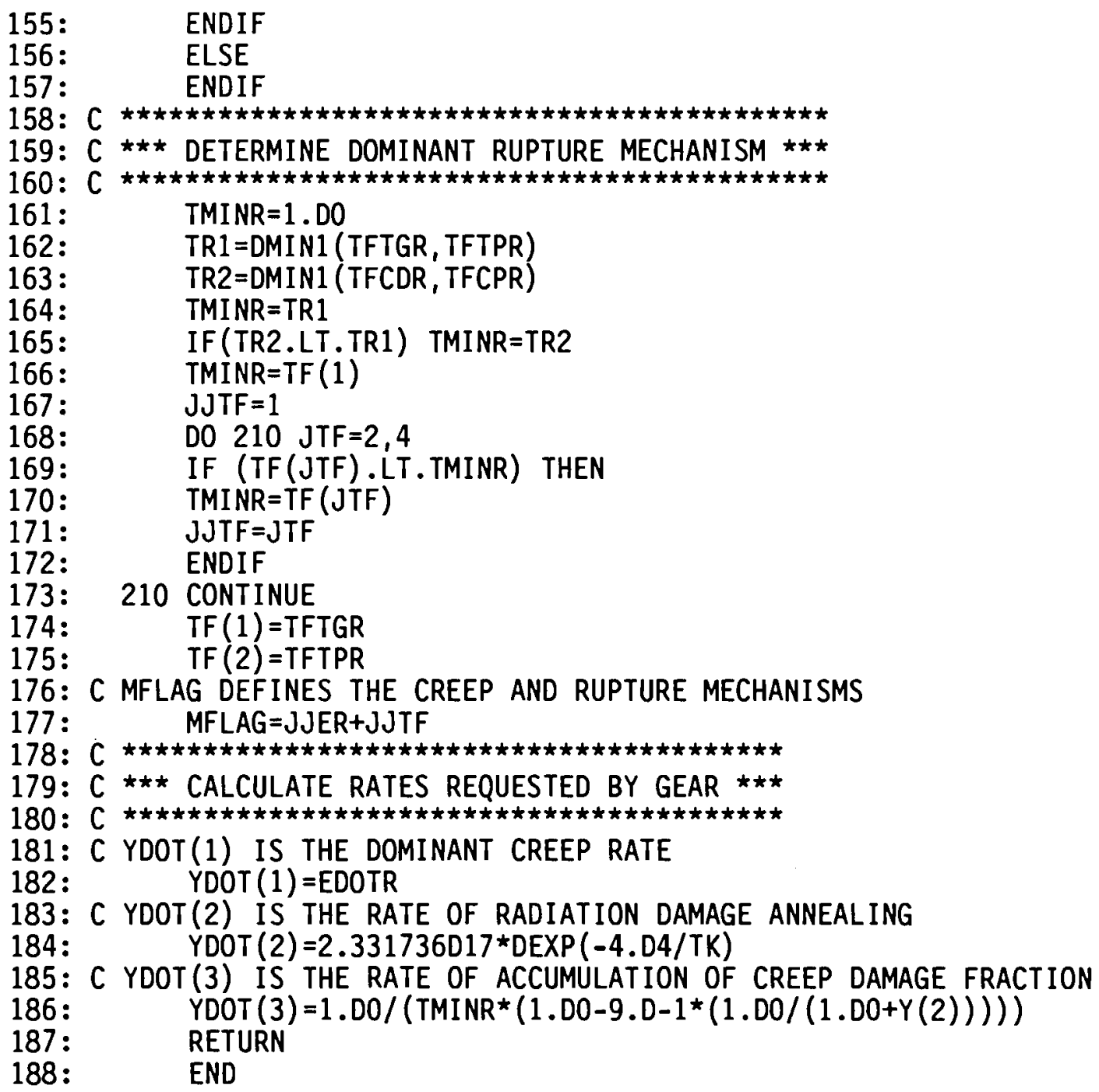


APPENDIX C

LISTING OF COMMON.FOR 


\section{LISTING OF COMMON.FOR}

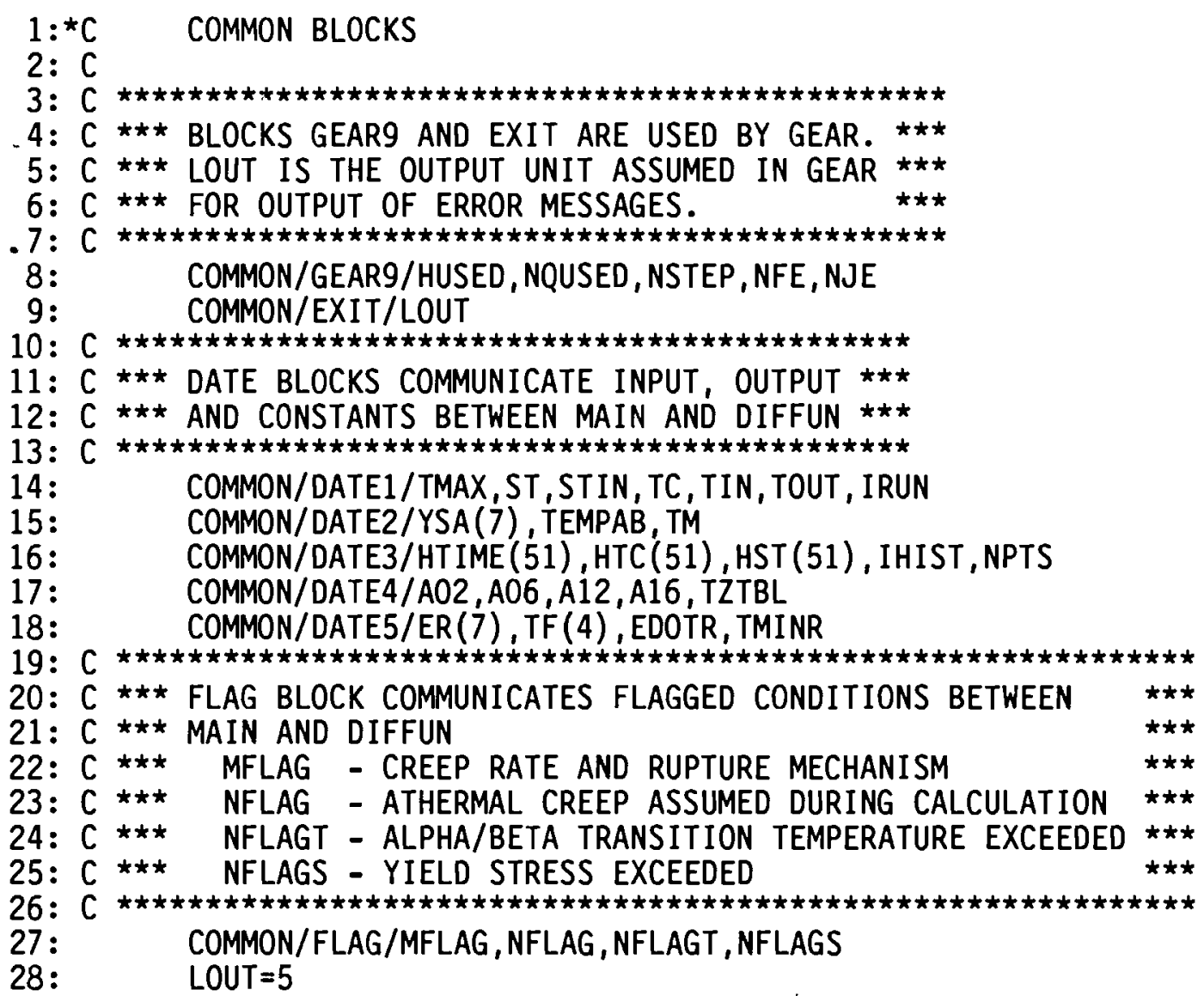




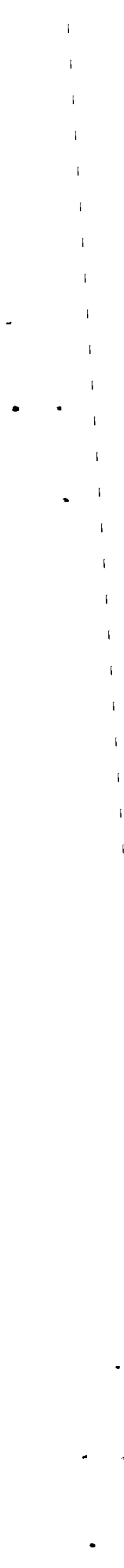


10 REM PLOT DATING.OUT FROM DATING FOR CUMULATIVE FRACTION OPTION

20 CLS

30 KEY OFF

$40 \operatorname{DIM} \operatorname{TI}(100), \operatorname{ST}(100), \operatorname{REC}(100), \operatorname{CF}(100), \operatorname{TC}(100), \operatorname{PAR}(6,100), \operatorname{ZSTR}(100)$

50 OPEN "DATING.OUT" FOR INPUT AS \#1

60 FOR JLIN=1 TO 18

62 INPUT \#1,ZLIN\$

64 NEXT JLIN

70 INPUT \#1,ZLIN\$

80 YLIN\$=RIGHT\$(ZLIN\$,5)

$90 \mathrm{HIST}=\mathrm{VAL}(\mathrm{YLIN} \$)$

100 REM LINE INPUT \#1,ZLIN\$

110 LINE INPUT \#1,ZLIN\$

120 LINE INPUT \#1,ZLIN\$

140 INPUT \#1,ZLIN\$

150 YLIN\$=RIGHT\$(ZLIN\$,5)

160 AGEIN=VAL (YLIN\$)

170 LINE INPUT \#1,ZLIN\$

180 LINE INPUT \#1,ZLIN\$

190 LINE INPUT \#1,ZLIN\$

200 LINE INPUT \#1,ZLIN\$

205 LINE INPUT \#1,ZLIN\$

210 YLIN\$=RIGHT\$(ZLIN\$,5)

$220 N S T=V A L(Y L I N \$)+1$

230 LINE INPUT \#1,ZLIN\$

232 JJLIN $=2$

234 IF HIST $=4$ THEN JJLIN $=1$

235 IF HIST $=4$ THEN 310

240 LINE INPUT \#1,ZLIN\$

250 LINE INPUT \#1,ZLIN\$

260 YLIN\$=RIGHT\$ (ZLIN\$,5)

270 TMAX $=$ VAL(YLIN\$)

280 LINE INPUT \#1,ZLIN\$

285 LINE INPUT \#1,ZLIN\$

290 YLIN\$=RIGHT\$ (ZLIN\$, 5)

$300 \quad S T R=V A L$ (YLINS)

310 FOR JLIN $=1$ TO JJLIN

320 LINE INPUT \#1,ZLIN\$

330 NEXT JLIN

335 IF NST $>100$ THEN NST $=100$

340 FOR LSTEP $=1$ TO NST

350 INPUT \#1, TI (LSTEP) , CF (LSTEP) , ST (LSTEP), REC (LSTEP), TC (LSTEP) , ZSTR (LSTEP)

$360 \operatorname{PAR}(1$, LSTEP) $=$ TI $($ LSTEP) $: \operatorname{PAR}(2$, LSTEP $)=\operatorname{ST}($ LSTEP $): \operatorname{PAR}(3$, LSTEP $)=\operatorname{REC}($ LSTEP)

$370 \operatorname{PAR}(4$, LSTEP $)=C F($ LSTEP $): \operatorname{PAR}(5$, LSTEP $)=\operatorname{TC}($ LSTEP $)$

380 NEXT LSTEP

390 REM INPUT \#1, TGEAR, I1GEAR, I2GEAR, I3GEAR, I IGEAR

*400 REM INPUT \#1, AGEIN

410 CLOSE \#1

$420 A \$=" C F ": L L P=4$ 
430 REM GOTO 240

440 CLS

442 IF HIST $=4$ THEN TMAX $=$ TC (1)

444 IF HIST $=4$ THEN STR=ZSTR(1)

450 PRINT "TMAX $="$; TMAX $; "$ STRESS $="$; STR

460 PRINT "YEAR"; TAB (10); "STRAIN"; TAB(25); "RECOVERY"; TAB (40); "Cum Frac dam"; TAB (55); "TEMP, C"; TAB (65); "STRESS, MPA"

470 FOR LSTEP $=1$ TO NST

480 PRINT TI (LSTEP); TAB (10); ST (LSTEP); TAB (25); REC(LSTEP); TAB (40); CF (LSTEP); TAB (55);TC(LSTEP) ; T

$A B(65) ; Z S T R$ (LSTEP)

490 NEXT LSTEP

500 LOCATE 25,1

510 INPUT "ENTER PLOT TYPE: CF, ST, REC, TC, TABLE, END? " , A\$

520 IF $A \$=" C F "$ THEN LLP=4

530 IF $A \$=" S T "$ THEN LLP=2

540 IF $A \$=" R E C "$ THEN LLP=3

550 IF $A \$=" T C "$ THEN LLP=5

560 IF $A \$=" E N D "$ THEN SYSTEM

570 IF $A \$=" T A B L E "$ THEN 440

$580 \operatorname{TIMAX}=\operatorname{TI}(1): \operatorname{STMAX}=\operatorname{ST}(1): \operatorname{RECMAX}=\operatorname{REC}(1): \operatorname{CFMAX}=\mathrm{CF}(1): \operatorname{TCMAX}=\operatorname{TC}(1)$

$590 \operatorname{TIMIN}=\operatorname{TI}(1): \operatorname{STMIN}=S T(1): \operatorname{RECMIN}=\operatorname{REC}(1): \operatorname{CFMIN}=C F(1): \operatorname{TCMIN}=\operatorname{TC}(1)$

600 FOR LSTEP $=2$ TO NST

610 IF TI (LSTEP) > TIMAX THEN TIMAX $=$ TI (LSTEP)

620 IF TI (LSTEP) $<$ TIMIN THEN TIMIN=TI (LSTEP)

630 IF ST(LSTEP) >STMAX THEN STMAX $=S T$ (LSTEP)

640 IF ST(LSTEP) <STMIN THEN STMIN=ST(LSTEP)

650 IF REC (LSTEP) > RECMAX THEN RECMAX=REC (LSTEP)

660 IF REC (LSTEP) $<$ RECMIN THEN RECMIN=REC(LSTEP)

670 IF CF (LSTEP) >CFMAX THEN CFMAX $=$ CF (LSTEP)

680 IF CF (LSTEP) <CFMIN THEN CFMIN=CF (LSTEP)

690 IF TC (LSTEP) >TCMAX THEN TCMAX=TC (LSTEP)

700 IF TC (LSTEP) <TCMIN THEN TCMIN=TC(LSTEP)

710 NEXT LSTEP

720 REM END

$730 \mathrm{KEY}$ OFF

740 REM DETERMINE NUMBER IN FORM X.XXENN

750 FOR LMAX $=1$ TO 5

760 IF LMAX $=1$ THEN X1=TIMAX:XMIN=TIMIN

770 IF LMAX $=2$ THEN $X 1=S T M A X: X M I N=S T M I N$

780 IF LMAX $=3$ THEN $X 1=$ RECMAX:XMIN=RECMIN

790 IF LMAX $=4$ THEN $X 1=$ CFMAX:XMIN=CFMIN

800 IF LMAX $=5$ THEN $X 1=$ TCMAX $: X M I N=T C M I N$

$810 \mathrm{~K}=-1$

820 IF INT $(X 1)=0$ AND INT $(10 * X 1) \diamond 0$ THEN XMAX $=X 1:$ GOTO 940

830 IF INT $(X 1)>0$ THEN 890

$840 \times 2=x 1$

$850 \times 2=\times 2 * 10$

$860 \mathrm{~K}=\mathrm{K}-1$

870 IF INT $(X 2)=0$ AND INT $(10 * X 2) \diamond 0$ THEN XMAX $=X 2: G 0 T 0940$

880 GOTO 850

$890 \times 2=\times 1$

$900 \times 2=\times 2 / 10$ 


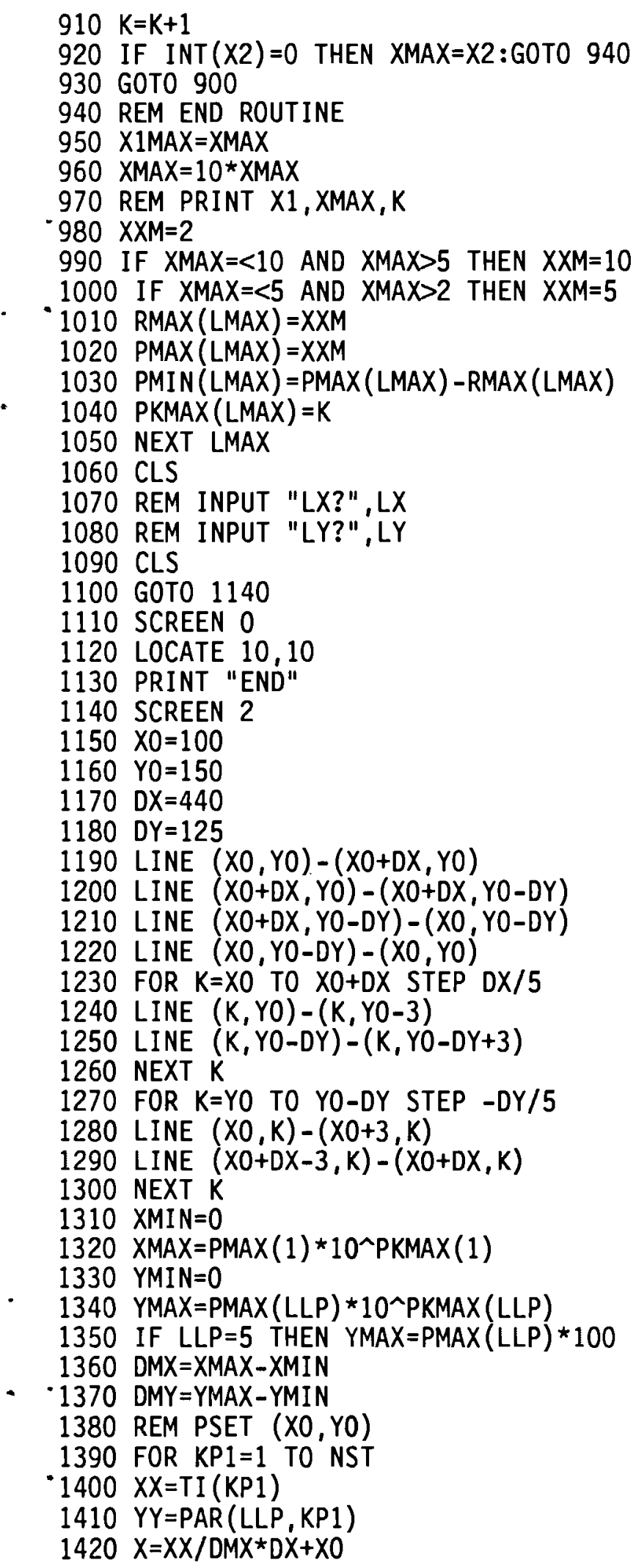




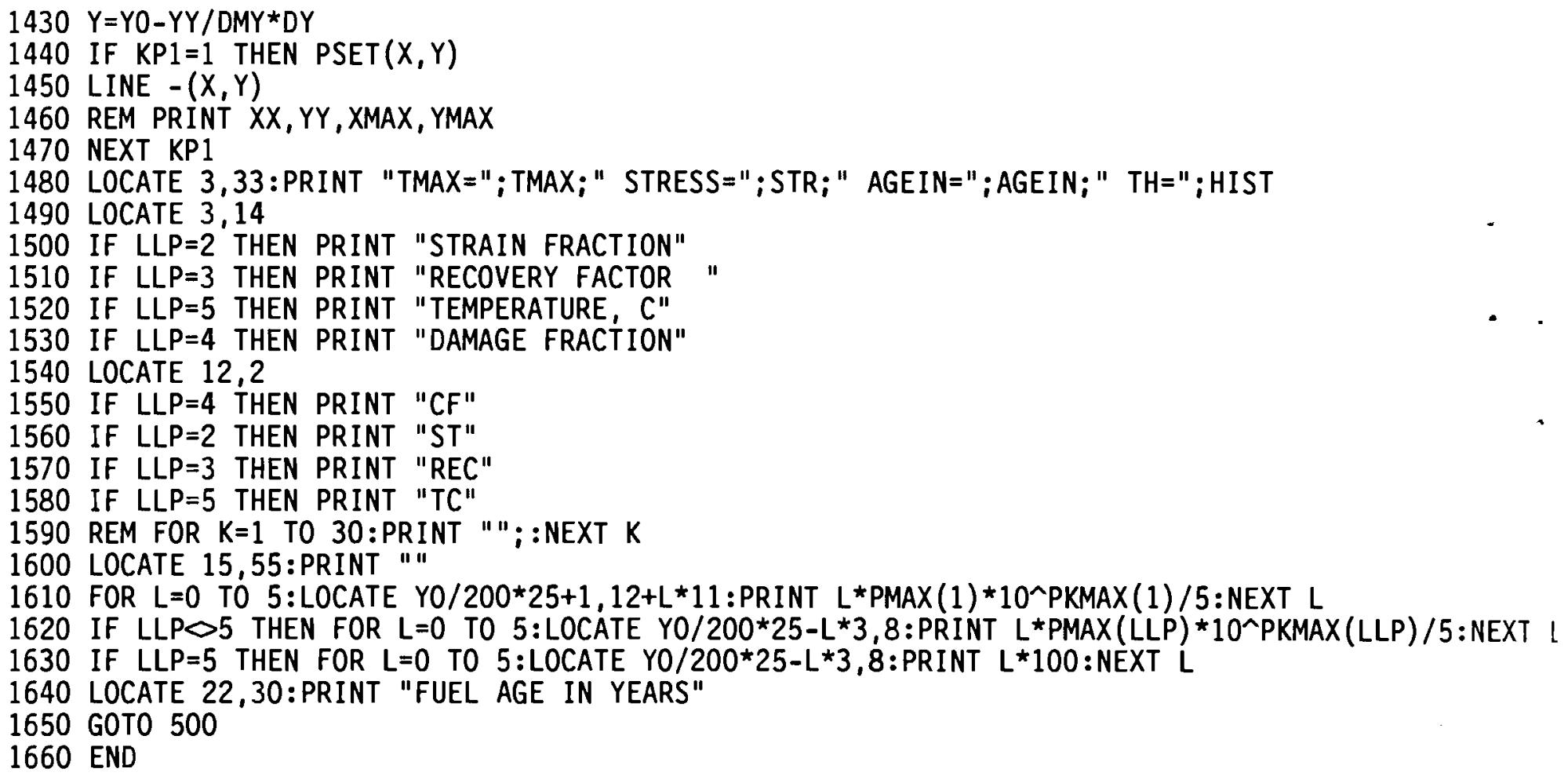




\section{DISTRIBUTION}

No. of

Copies

\section{OFFSITE}

10 DOE/Office of Scientific and Technical Information

R. Stein

Office of Civilian Radioactive Waste Management

U.S. Department of Energy

$\mathrm{RW}-30$

Washington, DC 20585

T. Nguyen

Office of Civilian Radioactive Waste Management

U.S. Department of Energy

RW-32

Washington, DC 20585

W. Danker

Office of Civilian Radioactive Waste Management

U.S. Department of Energy

RW-33

Washington, DC 20585

K. A. Klein

Office of Civilian Radioactive Waste Management

U.S. Department of Energy

RW-32

Washington, DC 20545

C. Head

Office of Civilian Radioactive Waste Management

U.S. Department of Energy

RW-32

Washington, DC 20545

J. S. Finucane

Energy Information

Administration

U.S. Department of Energy

EI -53

Washington, DC 20545
No. of

Copies

K. G. Golliher

U.S. Department of Energy

Albuquerque Operations Office

P.0. Box 5400

Albuquerque, NM 87115

S. Mann

U.S. Department of Energy

Chicago Operations Office

Argonne, IL 60439

M. Fisher

U.S. Department of Energy

Idaho Operations Office

785 DOE Place

Idaho Falls, ID 83402

S. T. Hinschberger

U.S. Department of Energy

Idaho Operations office

785 DOE Place

Idaho Falls, ID 83402

C. Matthews

U.S. Department of Energy

Oak Ridge Operations Office

P.0. Box E

Oak Ridge, TN 37830

C. J. Dankowski

U.S. Department of Energy Defense Programs

San Francisco Operations Office

1333 Broadway

Oakland, CA 94612

C. P. Gertz

U.S. Department of Energy

Waste Management Project Office

P.0. Box 98518

Las Vegas, NV 89193-8518 
No. of

Copies

10

J. Carter

National Energy Software Center

Argonne National Laboratory 9700 South Cass Avenue

Argonne, IL 60439

B. A. Chin

Auburn University

Mechanical Engineering Dept.

247 Wilmore Laboratories

Auburn, AL 36830

P. Childress

Babcock \& Wilcox Co.

P.0. Box 10935

Lynchburg, VA 24506-0935

L. A. Walton

Babcock \& Wilcox Co.

P.0. Box 10935

Lynchburg, VA 24506-0935

P. A. File

Baltimore Gas and Electric Co.

Calvert $\mathrm{Cl}$ iffs Nuclear Power Plant

Lusby, MO 20657

R. Kohli

Battelle, Columbus Division

505 King Avenue

Columbus, $\mathrm{OH} 43201$

V. Pasupathi

Battelle, Columbus Division

505 King Avenue

Columbus, $\mathrm{OH} 43201$

5 T. W. Wood

Battelle, Pacific Northwest Laboratories

370 L'Enfant Promenade SW Washington, DC 20024-2115

G. H. Beeman

Battelle, Pacific Northwest Laboratories

370 L'Enfant Promenade SW

Washington, DC 20024-2115
No. of

Copies

J. A. Carr

Battelle, Project Management Division

Office of Nuclear Waste Isolation

505 King Avenue

Columbus, $\mathrm{OH} 43201$

G. A. Townes

BE Inc.

P.0. Box 145

New Ellenton, SC 29809

L. J. Jardine

Bechtel National Inc.

P.0. Box 3965

San Francisco, CA 94119

G. E. Lucas

University of California

Dept. of Chemical and Nuclear Engineering

Santa Barbara, CA 93106

D. R. Olander

University of California

647 San Fernando Avenue

Berkeley, CA 94707

R. Kunita

Carolina Power \& Light Co.

411 Fayetteville St.

P.0. Box 1551

Raleigh, NC 27602

L. Martin

Carolina Power \& Light Co.

411 Fayetteville St.

P.0. Box 1551

Raleigh, NC 27602

G. C. Jobson

Chem-Nuclear Systems, Inc.

One Greystone West Building

240 Stoneridge Drive, Suite 100

Columbia, SC 29210 
No. of

Copies

C. K. Anderson

Combustion Engineering, Inc.

1000 Prospect Hill Road

Windsor, CT 06095

N. Fuhrman

Combustion Engineering, Inc. 1000 Prospect Hill Road

Windsor, CT 06095

G. P. Wagner

Commonwealth Edison

Nuclear Stations Division

P.0. Box 767

Chicago, IL 60690

T. J. Marz

Consumers Power Company

1945 W. Parnall Road

Jackson, MI 49201

S. J. Raffety

Dairyland Power Coop.

2615 E. Ave. S.

LaCrosse, WI 54601

R. W. Rasmussen

Duke Power Company

P.0. Box 33189

Charlotte, NC 28242

Ebasco Services, Inc.

Two World Trade Center

New York, NY 10098

R. Stanford

Edison Electric Institute

1111 19th St., NW

Washington, DC 20036

R. Maughan

EG\&G Idaho, Inc.

P.0. Box 1625

Idaho Falls, ID 83415

R. W. Lambert

Electric Power Research Institute

P.0. Box 10412

Palo Alto, CA 94304
No. of

Copies

R. F. Williams

Electric Power Research Institute

P.0. Box 10412

Palo Alto, CA 94304

G. T. Zamry

Florida Power \& Light Co. $9250 \mathrm{~W}$. Flagler St.

Miami, FL 33174

FLUOR Engineers, Inc.

Advanced Technology Division

P.0. Box C-11944

Santa Ana, CA 92711-1944

B. K. Agarwal

FW Energy Applications, Inc.

110 Orange Avenue

Livingston, NJ 07039

E. Engles

General Electric Co.

Morris Operation

Morris, IL 60450

W. L. Dobson

Gilbert Associates, Inc.

P.0. Box 1498

Reading, PA 19603

V. J. Barnhart

GNSI

135 Darling Dr.

Avon, CT 06001

B. Handly

Houston Lighting \& Power Co.

Nuclear Fuels-SPII

12301 Kurland Dr.

Houston, TX 77034

E. R. Johnson

E. R. Johnson Associates, Inc. 11702 Bowman Green Drive Reston, VA 22090

J. A. McBride

E. R. Johnson Associates, Inc.

11702 Bowman Green Drive

Reston, VA 22090 
No. of

Copies

L. M. Trosten

LeBoeuf, Lamb, Leiby, \& MacRae

1333 New Hampshire Ave. NW

Washington, DC 20036

L. B. Ballou

Lawrence Livermore National Laboratory

P.0. Box 808

Livermore, CA 94550

L. D. Ramspott

Lawrence Livermore National Laboratory

P.0. Box 808

MS L404

Livermore, CA 94550

M. Schwartz

Lawrence Livermore National Laboratory

P.0. Box 808 - MS L197

Livermore, CA 94550

C. F. Smith

Lawrence Livermore National Laboratory

P.0. Box 808

Livermore, CA 94550

J. H. Garrity

Maine Yankee Atomic Power Co. Edison Drive

August, ME 04336

G. D. Whittier

Maine Yankee Atomic Power Co. Edison Drive

August, ME 04336

R. Whale

Michigan Public Service

Commission

6545 Mercantile Way

Lansing, MI 48909

M. Kupinski

Northeast Utilities Service Co.

P.0. Box 270

Hartford, CT 06101
No. of

Copies

H. Shaw

Lawrence Livermore National Laboratory

Waste Package Task, NNWSI

P.0. Box 808 - MS L206

Livermore, CA 94550

J. Houston

Nuclear Assurance Corp. 5720 Peachtree Parkway

Norcross, GA 30092

C. B. Woodhall

Nuclear Assurance Corp.

5720 Peachtree Parkway

Norcross, GA 30092

J. Clark

Nuclear Fuel Services

6000 Executive Blvd.

Rockville, MD 20852

B. Lehnert

NUTECH Engineers

145 Martinvale Lane

San Jose, CA 95119

G. J. Antonucci

NUS Corporation

910 Clopper Rd.

Gaithersburg, MD 20878

J. V. Massey

Reedy \& Associates

15951 Los Gatos Blvd., Suite 1

Los Gatos, CA 95032

J. Van Cleve

Oak Ridge National Laboratory

P.0. Box X

Oak Ridge, TN 37831

M. Litterman

Portland General Electric, Trojan Fuel

121 SW Salmon St.

Portland, OR 97204 
No. of

Copies

D. Woods

Ralph M. Parsons Co.

700 West Walnut Street

Pasadena, CA 91124

A. A. Fuierer

Rochester Gas and Electric

Corporation

89 East Avenue

Rochester, NY 14649-0001

G. C. Allen

Sandia National Laboratory

Division 6323

Transportation Technology Center

P.0. Box 5800

Albuquerque, NM 87185

J. F. Ney

Sandia National Laboratory

Division 6323

Transportation Technology Center

P.0. Box 5800

Albuquerque, NM 87185

T. L. Sanders

Sandia National Laboratory

P.0. Box 5800

Albuquerque, NM 87185

E. Kuhns

Stone and Webster Engineering Corp.

1 Penn Plaza

250 w. 34th St.

New York, NY 10119

E. Gordon

Transnuclear, Inc.

507 Newmark Esplanade

Rockville, MD 20850

J. Mangus $i$

Transnuclear, Inc.

1 N. Broadway

White Plains, NY 10601

B. R. Teer

Transnuclear, Inc.

1 N. Broadway

White Plains, NY 10601
No. of

Copies

TRW, Exploration/Pro

P.0. Box 441807

Houston, TX 77244-1807

M. Keyhani

University of Tennessee

College of Engineering

414 Dougherty Eng. Bldg.

Knoxville, TN 37996-2210

R. J. Mullin

Tennessee Valley Authority

1101 Market St.

BR6N Space 40A

Chattanooga, TN 37402

F. C. Sturz

U.S. Nuclear Regulatory Commission

Office of Nuclear Materials Safety and Safeguards

Washington, DC 20555

C. Feldman

U.S. Nuclear Regulatory Commission

Office of Nuclear Materials Safety and Safeguards

Washington, DC 20555

W. R. Pearson

U.S. Nuclear Regulatory Commission

Regulatory Applications Division

MS NL-007

Washington, DC 20555

C. H. Peterson

U.S. Nuclear Regulatory Commission

Office of Nuclear Materials Safety and Safeguards

MS 623-SS

Washington, DC 20555 
No. of

Copies

J. Roberts

U.S. Nuclear Regulatory Commission

Office of Nuclear Materials Safety and Safeguards

Washington, DC 20555

L. C. Rouse

U.S. Nuclear Regulatory Commission

Division of Fuel Cycle Material Safety

Washington, DC 20555

S. P. Ture 1

U.S. Nuclear Regulatory Commission

Office of Nuclear Materials Safety and Safeguards

Washington, DC 20555

P. K. Shaver

U.S. Tool and Die, Inc. 4030 Route 8

Allison Park, PA 15101

W. J. Wachter

U.S. Tool and Die, Inc.

1465 Glenn Avenue

Glenshaw, PA 15116

J. A. Nevshemal

Toledo Edison Co.

2155 Kathy Lane

Genoa, $\mathrm{OH} 43430$

E. A. Bassler

Westinghouse Electric Corp.

P.0. Box 2728

Pittsburgh, PA 15230

C. F. Davis

Westinghouse Electric Corp.

Waste Technology Services Div.

P.0. Box 10864

Pittsburgh, PA 15236

P. S. Klanian

Westinghouse Electric Corp. c/o West Valley Nuclear Services P.0. Box 191

West Valley, NY 14171
No. of

Copies

E. Benz

R. F. Weston Co.

955 L Enfant Plaza SW

8th Floor

Washington, DC 20024-2119

N. Dayem

R. F. Weston Co.

955 L Enfant Plaza SW

8th Floor

Washington, DC 20024-2119

\section{ONSITE}

2 DOE Richland Operations Office

D. E. Kenyon

E. C. Norman

1 Westinghouse Hanford Company

C. L. Brown

74 Pacific Northwest Laboratory

M. J. Apted

W. J. Bailey

J. 0. Barner

C. E. Beyer

D. J. Bradley

H. C. Burkholder

T. K. Campbell

T. D. Chikalla

J. M. Creer (5)

M. E. Cunningham

P. G. Doctor

R. E. Einziger

M. D. Freshley

E. R. Gilbert (20)

R. J. Guenther

R. F. Hazelton

C. M. Heeb

R. E. Heineman

A. B. Johnson, Jr.

R. W. Knoll

M. R. Kreiter

D. D. Lanning

S. C. Marschman

J. L. McElroy 
PNL-6639

UC-85

No. of

Copies

M. A. McKinnon

J.T.A. Roberts

D. J. Silviera

E. P. Simonen (10)

0. D. Slagle

H. D. Smith

R. I. Smith

J. L. Straalslund

L. A. Strope

C. K. Thornhill

R. C. Walling

C. N. Wilson

Publishing Coordination

Technical Report Files (5) 
